\title{
Ostracods as palaeoenvironmental indicators in the Lower Carboniferous Yoredale Series of northern England
}

\author{
H. MASUREL
}

Instituut voor Aardwetenschappen, Vrije Universiteit, P.O. Box 7161, 1007 MC Amsterdam,

The Netherlands.

\begin{abstract}
The ostracod fauna and vertical changes in its composition were examined in a shale sequence of the 5-Yard Limestone cyclothem (Yoredale Series) at a locality in Bishopdale, N. Yorkshire. The ostracod tax a are mainly confined to three superfamilies: Kirkbyacea, Healdiacea and Bairdiacea. The co-occurrence of several relatively short-ranging species such as Kirkbya quadrata, Cribroconcha insculpta and Bairdiolites elevatus suggests a Late Brigantian age. Four new species are described: Cornigella posteroextensa, "Ericlla minima, Rectobairdia bavarica and Roundyella binoda.

Fluctuations in influx of terrigenous mud and water turbulence, related to delta growth, appear to have been the main environmental parameters that controlled the ostracod distribution and abundance along a nearshore-offshore gradient. Three different ostracod assemblages are recognized. A Roundyella-Cribroconcha assemblage, dominated by kirkbyacean and healdiacean ostracods, represents a quiet, nearshore environment with a fairly high depositional rate of terrigenous mud. A Bairdia assemblage, higher in the section, is dominated by bairdiacean ostracods that lived in a more turbulent, relatively offshore environment with less input of terrigenous sediment. A third, intermediate assemblage consists of almost equal amounts of bairdiacean and kirkbyacean ostracods, and reflects a transition from the Bairdia to the Roundyella-Cribroconcha assemblage.
\end{abstract}

\section{INTRODUCTION: PALAEOGEOGRAPHY AND SEDIMENTATION}

The 5-Yard Limestone cyclothem is one of the cyclothems of the Yoredale Series of Great Britain that was deposited during the Brigantian stage in late Lower Carboniferous times (Moore, 1958), not far south of the Carboniferous equator (fig. 1). As described in an earlier paper (Masurel, 1987), Great Britain then was an area of high relief with uplifted mountain chains in Scotland adjacent to major interior basins, and block and basement tectonics in northern England, subsequently inundated by marine sedimentation spreading across the British continental shelf from south to north. The basal bioclastic limestones and overlying shales and sandstones of the Yoredale succession reflect the passage from clear, limestone-forming seas to terrigenous delta progradation from the north.

\section{METHODS OF STUDY}

One of the sections of the 5-Yard Limestone cyclothem described by the author in 1987 (section 5; p. 231-236, figs. $1,5 c, 7,8$, table ID), was selected for the purpose of this study. It is located in Bishopdale, N. Yorkshire (fig. 1,2).

Samples were collected from horizons throughout the section. The purpose was to investigate the palaeo-environmental conditions that have been involved with vertical changes of lithology and fossil content in the stratigraphical column. Therefore, sampling horizons were widely spaced in relatively monotonous parts of the column, but closer where changes in lithology are distinct, e.g. the shale hori-

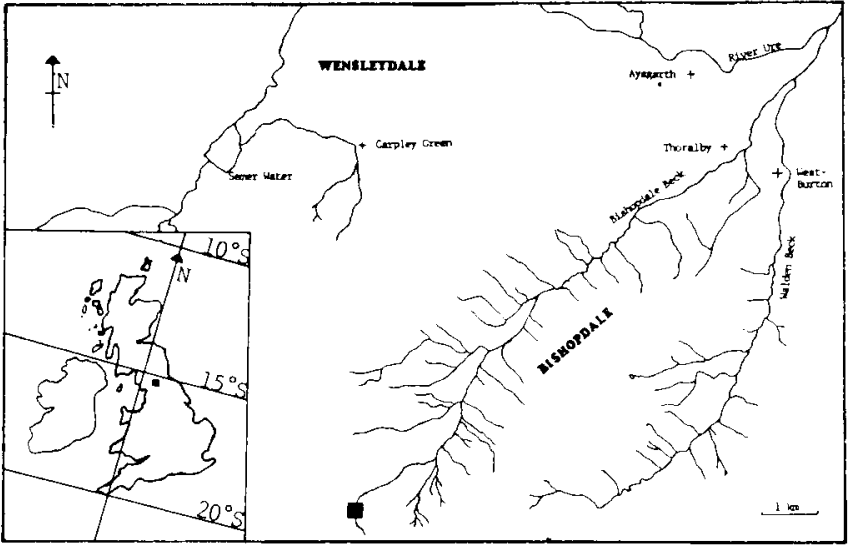

Fig. I Location of the section (marked by black square), $\mathrm{N}$. Yorkshire, Great Britain; generalised palaeolatitude in the Early Carboniferous, based on palaeomagnetic data (McElhinny, 1973).

zons below, in and above the nodule beds and the Gigantoproductus zone (fig. 3, 4).

Sample material was oven-dried, weighed, and then immersed in petroleum. After about 2 hours the petroleum was replaced by boiling water, and the disaggregated material was wet-sieved and separated into different fractions.

\section{PALAEOECOLOGY}

The largest part of the sequence is characterised by a scarcity of ostracods. It is doubtful if the ostracods, which are often 
disarticulated, are autochtonous. Ostracods and other bioclasts often show some degree of pyritisation, which indicates that deposition of mud took place under quiet, reducing conditions. Poor oxygenation of the water and a fairly high influx and depositional rate of clay may have been important limiting factors preventing most organisms from colonising the sea floor. Shales that exhibit a relatively high abundance and diversity of ostracods and other bioclasts are largely confined to horizons below the $75 \mathrm{~cm}$ sample, in and around the three main nodule beds, and above the third nodule bed (fig. 3, 4). These probably reflect periods of decreased sedimentation rate linked with a temporarily increased water turbulence. Most of the ostracods that occur here do not show signs of post-mortem transport, and probably formed part of autochtonous populations. Their shells are usually articulated and various growth stages are found. Several specimens of spinose forms such as Cornigella tuberculospinosa and Cribroconcha insculpta have been found with their spines still intact. The associated, stenohaline macrofauna which occurs at most of these fossiliferous shate horizons is dominated by benthic suspension feeders, most of which are probably indigenous. This, together with local concentrations of fossil debris, implies deposition in shallow, well-oxygenated water of normal marine salinity (Masurel, 1987).

The nodules that occur at 3 distinct, relatively fossiliferous shale horizons have been described by the present author (Masurel, 1987) and are interpreted as being algal in origin, since laminated structures were occasionally found in their Fe-rich matrix (dolomicrosparite). Furthermore, the matrix shows minor bioturbation phenomena and vague relicts of brachiopods, bryozoa, foraminifera and ostracods in cracks subsequently filled by calcite. The formation and diagenetic history of these nodules is probably analogous to that of septarian concretions, which are not uncommon in clayey sediments (Vandenberghe \& Laga, 1986; Astin \& Scotman, 1988). The nodule beds represent carbonate-rich sedimentation horizons, resulting from periods of reduced clay sedimentation. During these periods conditions apparently were suitable for growth of algae, which may have formed algal mats that were suitable for attachment by suspension feeders such as brachiopods and bryozoa. Nodules were formed as result of remobilisation and redistribution of carbonate at an early diagenetic stage, the final shape being determined by the original thickness of the carbonate-rich sedimentation horizon and the amount of carbonate available in the horizon (Vandenberghe \& Laga, 1986).

\section{ASSEMBLAGES}

\section{Roundyella binoda n. sp. - Cribroconcha caneyensis Assemblage}

This assemblage occurs in dark grey, finely laminated, organic-rich mud-shales at $25 \mathrm{~cm}, 190-200 \mathrm{~cm}, 500-560 \mathrm{~cm}$ and $1075 \mathrm{~cm}$ and less distinctly at other horizons. The assemblage can be divided into 3 subassemblages, based upon the relative occurrence of its two end members (see figs. 3, 4):

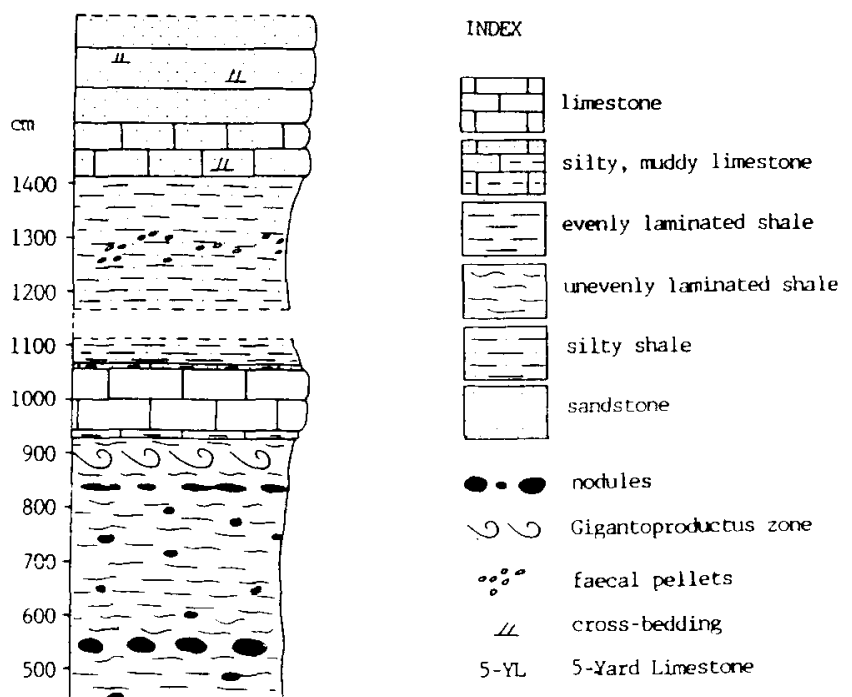

For sampling positions see fig. 3 .

A. Roundyella binoda dominates the ostracod fauna (400), $1075 \mathrm{~cm}$ ), and is associated with only a scarcity of other taxa including Cribroconcha caneyensis.

B. Roundyella binoda and Cribroconcha caneyensis together dominate the ostracod fauna, which exhibits a variable diversity of other species $(500-550 \mathrm{~cm})$.

C. Cribroconcha caneyensis dominates, and is associated with a relatively high abundance and diversity of other species $(560 \mathrm{~cm})$.

Sub-assemblages $\mathrm{B}$ and $\mathrm{C}$ sometimes include significant numbers of the following ostracod taxa: Scrobicula scrobiculata, Amphissites urei, Kirkbya quadrata, Healdianella cf. darwinuloides and Cribroconcha insculpta. Accessory components in these sub-assemblages are Bairdiolites elevatus, Cornigella tuberculospinosa, Hollinella radiata, Tetrasacculus mirabilis, Moorites elongatus, and several others (fig. 4). It is noted that a relatively low diversity characterises sub-assemblage B in a sample from $500 \mathrm{~cm}$, Scrobicula scrobiculata being the only important component that co-occurs with the two end members. The occurrence of the two kirkbyaceans Amphissites urei and Kirkbya quadrata is largely confined to fossiliferous shales between 540 and $560 \mathrm{~cm}$ (fig. 3). The diversity of microfauna as well 


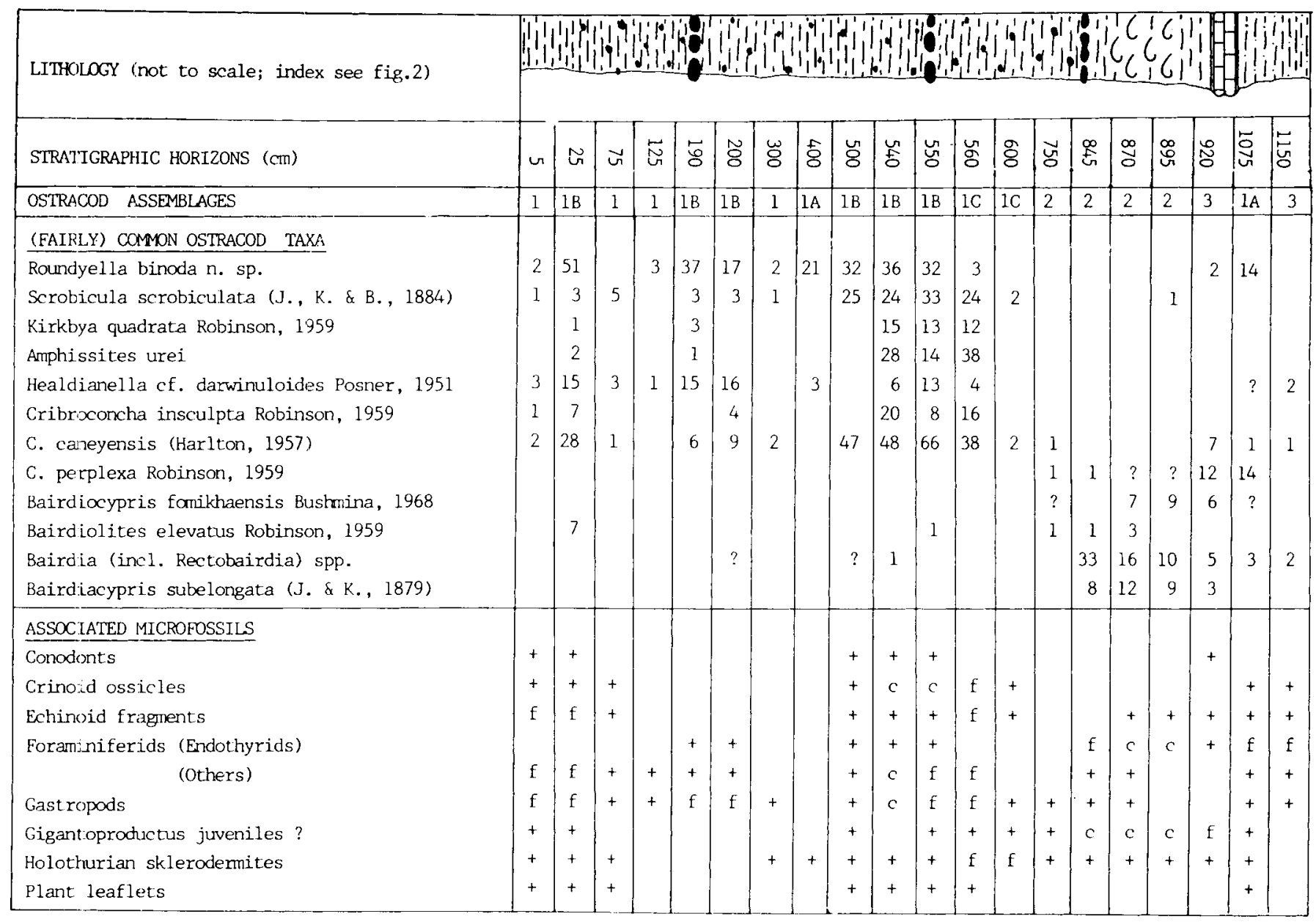

Fig. 3 Distribution chart of ostracode taxa and associated microfossils. The number of specimens was counted in 50 gramsamples;,$+ f$ and $c$ respectively represent a sporadical ( $1-5)$, fairly common (5-20) and common occurrence (20 or more), and ? a questionable assignment.

as macrofauna (Masurel, 1987): table ID) shows a relatively high peak at these horizons. Amphissites and Kirkbya probably needed well oxygenated water for growth of their fairly large and elaborate carapaces.

Where the assemblage reappears at $1075 \mathrm{~cm}$, just above the thin limestone, it is characterised by a low density and diversity (figs. 3,4). A new, relatively common component is Cribroconcha perplexa, which was already fairly common in a transitional assemblage detected somewhat lower in the section (920 cm, see below).

\section{Bairdia assemblage}

This assemblage occurs in coarsely laminated, calcareous shales in and above the highest nodule bed, between 845 and $920 \mathrm{~cm}$ (fig. 2).

Bairdia is the most characteristic genus of the assemblage, associated with other bairdiaceans including Rectobairdia spp., Bairdiacypris spp., and, less commonly, Bairdiolites elevatus. Poor preservation of most of the ostracods in the calcareous shales made identification of species very dif- ficult, but it is eliminated that there are probably more than 10.

Bairdiaceans are by far the most abundant ostracods in samples derived from $845 \mathrm{~cm}$. The only accessory component of the assemblage is Cribroconcha perplexa, which is not found at lower horizons. The abundance of Gigantoproductus shows a peak slightly higher in the sequence, between 870 and $898 \mathrm{~cm}$. Gigantoproductus was probably an opportunist that took advantage of a reduced mud sedimentation rate, an increased water turbulence supplying sufficient food and oxygen, and a lack of competition by other large benthic suspension feeders (Masurel, 1987, p. 232-233, fig. 8 ).

It appears that the bairdiacean ostracods had already become established before the explosive colonisation by this large brachiopod.

Bairdiocypris joins the assemblage at $870 \mathrm{~cm}$, and remains a fairly common component.

Assemblages dominated by bairdiacean ostracods are indicative of offshore marine environments. Late Palaeo- 
zoic faunas in which bairdiacean ostracods predominate have been described by many authors, e.g. Brondos \& Kaesler (1976), Haack \& Kaesler (1980), Bless (1983), Kaesler (1983), Crasquin (1984) and Devery (1987). Kornicker (1961) described ostracod associations from recent stable offshore sediments which were also dominated by bairdiaceans. This author concluded that an abundance of Bairdia specimens in ancient sediments may indicate deposition in shallow, warm (above $10^{\circ} \mathrm{C}$ ) water of normal marine salinity (30-40 parts per thousand).

The fact that bairdiaceans do not reach significant numbers in the lower part of the sequence would suggest that conditions remained hostile to them. Only Bairdiolites elevatus appears to have been a fairly adaptable species, an inference drawn from its fairly common occurrence (in different growth stages) in a sample from $25 \mathrm{~cm}$ (fig. 3).

Accessory ostracods that were found in samples from 870 $\mathrm{cm}$ and $895 \mathrm{~cm}$ are Coryellina retic os $a$ and the paraparchitaceans Shishaella cf. williamsae and Shivaella armstrongiana. The last two were typical inhabitants of shallow offshore environments (Bless, 1983).

\section{Transitional assemblage}

This assemblage occurs in coarsely laminated, calcareous shales above the Gigantoproductus zone $(920 \mathrm{~cm})$. It represents a transition from the Bairdia assemblage into the Roundyella-Cribroconcha assemblage, indicating a gradual change of palaeo-environmental conditions.

Assemblage 3 consists of almost equal numbers of bairdiaceans (Bairdia, Bairdiacypris) and healdiaceans (Cribroconcha canevensis, $C$. perplexa), associated with only a few specimens of the kirkbyacean Roundyella binoda.

A common occurrence of healdiid ostracods is often assumed to be indicative of relatively nearshore, muddy conditions (e.g. Bless, 1983 and Melnyk, 1985). It is therefore suggested that the main reason for the change in the ostracod fauna and for the extinction of Gigantoproductus may have been a slight increase of mud influx and sedimentation rate, related to a slowly retreating shoreline. Gigantoproductus, which probably had taken advantage of a temporarily reduced sedimentation rate, appears to have become locally extinct very quickly (Masurel, 1987, fig. 8), even before the appearance of significant amounts of healdiaceans in the ostracod fauna. Opportunists are characterised by relatively unstable populations, and often become extinct quickly at the onset of unfavourable conditions (Levinton, 1970).

\section{CONCLUSIONS AND DISCUSSION Depositional environment}

The main part of the shale sequence, characterised by a scarcity of ostracods, was deposited in quiet shallow water of the prodelta area. Poor oxygenation of the water and a high influx of terrigenous mud probably inhibited colonisation by ostracods and other benthic organisms. Nevertheless, fairly diverse ostracod assemblages, sometimes containing more than 15 species, have been recognised at several different shale horizons. These are usually associated with a diversity of other microfossils (fig. 3), and an autochtonous macrofauna consisting mainly of suspension feeders, including stenohaline rugose corals (Masurel, 1987). The fossiliferous shale horizons thus reflect episodes of temporarily increased water circulation and reduced influx and deposition of mud under normal marine salinity conditions.

Assemblage 1 consists mainly of kirkbyacean and healdiacean ostracods (Fig. 3: 190.550 cm). These must have had some tolerance to the influx of clay under very quiet conditions. The assemblage is dominated by either one or both of its end members, the ratio between which forms a basis for further division into 3 sub-assemblages (1 A, 1B, 1C). Roundyella binoda was probably the most adaptable species, dominating a very impoverished ostracod fauna (sub-assemblage 1 A at $400 \mathrm{~cm}$, where other, often pyritised bioclasts only sporadically occur (Fig. 3,4). At other shale horizons, where both end members or only Cribroconcha canevensis dominate (sub-assemblages $1 \mathrm{~B}$ and $1 \mathrm{C}$ ), a fairly high diversity of ostracod species is usually found.

The most important and consistent components of assemblage 1, besides its end members, are Scrobicula scrobiculata, Amphissites urei. Kirkbya quadrata. Healdianella cf. darwinuloides and Cribroconcha insculpta.

Assemblage 2 is dominated by bairdiacean ostracods (Fig. 3: $845 \mathrm{~cm}$ ), occurring in calcareous shales. It probably occupied a more offshore, open marine environment that was less influenced by the delta. Micro- and macrofauna contain evidence of a considerably reduced sedimentation rate of mud in well oxygenated, nutrient-rich, shallow water.

Assemblage 3 is transitional between assemblages 1 and 2 , consisting of almost equal numbers of bairdiacean and healdiacean ostracods, associated with considerably fewer kirkbyaceans (Fig. 3: $920 \mathrm{~cm}$ ). This assemblage reflects depositional conditions which are intermediate between that of the relatively nearshore, clastic-dominated environment of the kirkbyaceans and healdiaceans (assemblage 1), and the more offshore, carbonate-dominated environment of the bairdiaceans (assemblage 2 ).

The ostracod assemblages and related palaeo-environmental conditions described above are comparable with those recognised by Devery (1987), in the Bangor Limestone Formation (Chesterian, Mississippian) of Alabama. He described ostracods from intercalations of argillaceous limestones and calcareous shales, which were probably deposited in a middle shelf-carbonate environment where delta progradation played an important role. Salinity percentages probably remained within normal marine levels. Devery related his assemblages to a nearshore-offshore gradient, and concluded that fluctuations in the influx of terrigenous sediment and small variations in salinity were probably the main environmental parameters that controlled the ostracod distribution along the nearshore-offshore coenocline.

The Roundyella-Cribroconcha assemblage (1) is comparable with the Kirkbyella gutkei subassemblage recognised 


\begin{tabular}{|c|c|c|c|c|c|c|c|c|c|c|c|c|c|c|c|c|c|c|c|c|}
\hline STRA'IIGRAPHIC HORIZONS $(\mathrm{cm})$ & 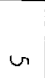 & $\tilde{\sim}$ & $\vec{H}$ & G & 学 & $\tilde{8}$ & $\ddot{8}$ & 8 & है & 㟧 & ज্ㅇ & 资 & 8 & ज্ㅇ & $\begin{array}{l}\infty \\
\stackrel{\infty}{\sharp}\end{array}$ & $\stackrel{\infty}{\partial}$ & 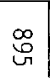 & 岕 & 灾 & $\bar{F}$ \\
\hline OSTRACOD ASSEMBLAGES & 1 & 1B & 1 & 1 & 1B & $1 B$ & 1 & $1 \mathrm{~A}$ & 18 & $1 B$ & $1 B$ & $1 \mathrm{C}$ & $1 C$ & 2 & 2 & 2 & 2 & 3 & $1 \mathrm{~A}$ & 3 \\
\hline $\begin{array}{l}\text { LESS COMMN OSTRACOD TAXA } \\
\text { Bairdia (B.) beedei Ulrich \& Bassler, 1906 } \\
\text { B. (B.) harltoni Cooper, } 1946 \\
\text { B. (Rectobairdia) bavarica n. sp. } \\
\text { Bairdiacypris cf. curvis (Cooper, 1941) } \\
\text { B. sp. aff. robusta Kumerow, 1939 } \\
\text { Cavellina cf. benniei (J., K. \& B., 1884) } \\
\text { Cornigella posteroextensa n. sp. } \\
\text { C. tuberculospinosa (Jones \& Kirkby, 1886) } \\
\text { Coronakirkbya cormuta (Robinson, 1978) } \\
\text { Coryellina cf. reticosa (Jones \& Kirkby, 1886) } \\
\text { Cryptophylius sp. (Eridostracan ?) } \\
\text { Discoidella sp. } \\
\text { ? Eriella minima n. sp. } \\
\text { Healdia comigera (Jones \& Kirkby, 1879) } \\
\text { Hollinella radiata (Jones \& Kirkby, 1886) } \\
\text { Kegel.ites sp. } \\
\text { Mono.eratina antiqua (Jones \& Kirkby, 1886) } \\
\text { Moorites elongatus (Jones \& Kirkby, 1886) } \\
\text { Sargentina sp. } \\
\text { Shistraella cf. williamsae Sohn, 1971 } \\
\text { Shivaella armstrongiana (Jones \& Kirkby, 1886) } \\
\text { Tetrasacculus mirabilis (Croneis \& Gale, 1938) } \\
\text { Youngiella sp. }\end{array}$ & 1 & $\begin{array}{l}4 \\
2\end{array}$ & & & & $\begin{array}{l}1 \\
2\end{array}$ & & l & 1 & $\begin{array}{l}1 \\
2\end{array}$ & 1 & $\begin{array}{l}1 \\
?\end{array}$ & & & & $?$ & 1 & $\begin{array}{l}1 \\
2\end{array}$ & 1 & 1 \\
\hline
\end{tabular}

Fig. 4 Distribution chart of ostracode taxa not listed in fig. 3. The number of specimens was counted in 50 gram samples.

in the Sansabella assemblage of Devery, which is characterised by a large number of healdiaceans and kirkbyaceans, and thought to have occupied a nearshore environment.

The Bairdia assemblage (2) can be compared with Devery's subgroup 1 of the Bairdia golcondensis assemblage, characterised by an abundance of bairdiaceans and common occurrence of kirkbyaceans, associated with endothyracean foraminifera, indicative of the offshore environment.

The Transitional assemblage (3) is comparable with subgroup 2 of the Bairdia golcondensis assemblage of Devery, which contains a glyptopleurid-bairdiacean fauna and represents a transitional phase between a nearshore and an offshore assemblage.

\section{Biostratigraphy and palaeogeography}

The ostracod fauna of the 5-Yard Limestone cyclothem contains several short range species that have been recorded from the Cawdor Limestones of the Derbyshire massif, England (Robinson, 1959), and are diagnostic for the upper Brigantian stage, e.g. Cribroconcha insculpta, C. perplexa, Kirkbya quadrata and Bairdiolites elevatus. The stratigraphic range of two species that were known from the Pendleian to Arnsbergian of Great Britain (Robinson, 1978), Coryellina reticosa and Bairdia beedei, is here extended.

The fauna shows affinity to Lower Carboniferous ostra- cod faunas from Belgium, Germany, France, Russia and North Africa, described by several authors, e.g. Bushmina (1968, 1970, 1975), Becker \& Bless (1974), Becker et al. (1974), Bless \& Massa (1982) and Crasquin (1984). Several forms that are conspecific or closely related to Russian species, e.g. Shivaella armstrongiana, Bairdiocypris fomikhaensis and Bairdiacypris sp. aff. robusta, appear to occur later in western Europe than in Russia. This phenomenon was already noted by Bless (1983), and can be explained by considering palaeogeographic and palaeo-oceanic reconstructions of the Hercynian Ocean and adjacent areas during Visean times (Ziegler et al., 1979 and Dewey, 1985). A westward equatorial ocean current fed by the Uralian Ocean would have flowed along the northern margin of the Hercynian Ocean, whereas a weaker counter equatorial current would have flowed along the southern edge. extensive development of epicontinental shelves in the northern Hercynian Ocean further would have facilitated migration of ostracod larvae (Dewey, 1985). Evidence for westward migration can also be derived from the distribution of other faunal groups, such as conodonts. Higgins ( 1981) noted that the range of the cosmopolitan conodont species Paragnathodus commutatus is not identical in Eurasia and the Midcontinent of North-America. In Europe it appears at the base of the Visean, but in the Midcontinent its first appearance is in 
the late Visean.

The ostracod assemblages described in this paper are equivalent in age and partly conspecific to faunas from the Chesterian Kinkaid and Bangor Limestone formations of the Midcontinental United States (Cooper, 1942, 1947; Devery, 1987), and the upper units of the Codroy and Windsor Groups of Maritime Canada (Dewey, 1983, 1985 and Dewey \& Fîhraeus, 1987), all representing series of transgressive and regressive episodes. The chronostratigraphical relationship is based on several sources, e.g. Mamet (1970), Conil et al. (1976) and George et al. (1976). The Midcontinental faunas contain several forms that are conspecific to those described herein, such as Cribroconcha caneyensis, Cornigella tuberculospinosa and Tetrasacculus mirabilis. The assemblages from Maritime Canada are often dominated by paraparchitacean ostracods, and show considerably less similarities to both the Midcontinental and the faunas described herein. This can be explained by a restricted circulation of sea water and prevailing hypersaline conditions in the Maritime Basin, which was a shallow embayment of the Hercynian Ocean. Dewey (1985) considered the low affinity between the Midcontinental and eastern Canadian ostracod faunas to be a function of the Appalachian barrier and circulation of ocean currents away from the Midcontinent in northward direction. Data obtained in this study on the other hand provide evidence of a faunal connection between northern England and the Midcontinent during the late Visean, thus implying a less isolated position of the latter.

\section{SYSTEMATIC PALAEONTOLOGY}

The material described in this paper is housed in the collections of the Rijksmuseum van Geologie en Mineralogie, Leiden, The Netherlands, under reference numbers RGM $350.501-350.638$.

Synonymy lists are selective and refer only to important revisions and citations. Dimensions are in millimetres and the following abbreviations are employed: $R V$ right valve and LV left valve; DM dorsal margin and VM ventral margin; $L$ maximum length, $H$ maximum height and $W$ maximum width.

Class Ostracoda Latreille, 1806

Order Palaeocopida Henningsmoen, 1953

Suborder Beyrichicopina Scott, 1961

Superfamily Drepanellacea Ulrich \& Bassler, 1923

Family Aechminellidae Sohn, 1961

Genus Cornigella Warthin, 1930
Cornigella tuber'ulospinosa (Jones \& Kirkby, 1886)

(Pl. 6, figs. 2a, b)

Diagnosis. Carapace subovate-cuneiform in lateral view. DM straight, VM convex, ends rounded, anterior broader. Maximum height anterior of mid-length. Surface of each valve marked by a strong, slightly backward pointing dorsal spine (just posterior of mid-length) and six nodes.

1886 Beyrichia tuberculospinosa Jones \& Kirkby, p. 258, PI. 8, Figs. 7-8.

1947 Cornigella tuberculospinosa - Cooper, p. 89, P1. 21, figs. 4-6

1951 Cornigella tuberculospinosa-Posner, p. 43, Pl. 15, fig. 5.

1987 Cornigella tuberculospinosa var. A - Devery, p. 82, Pl. 3 , figs. 1-2.

Material. 4 carapaces, two of which are completely pyritised.

Description. The most prominent node is located in front of the dorsal spine, five others border the free margin at some distance, including a weakly developed node behind the dorsal spine. Surface regularly reticulated, spines and nodes almost smooth with scattered pits.

Remarks. Cornigella tuberculospinosa may show some variation in the number of nodes. The specimens described herein closely resemble those figured by Jones \& Kirkby (1886) and Devery (1987).

Occurrence: Upper Visean of Great Britain, Upper Mississippian to Pennsylvanian of U.S.A., Lower Carboniferous of U.S.S.R.

\section{Cornigella posteroextensa sp. nov.} (P1. 6, figs. la,b)

? 1987 Cornigella tuberculospinosa var. B - Devery, p. 82, Pl. 3, fig. 10.

Derivation of name. Latin, referring to extended posterior extremity, compared with C. tuberculospinosa (Jones \& Kirkby, 1886).

Diagnosis. Carapace subovate-cuneiform in lateral view. DM straight, VM convex, ends rounded, anterior broader. Maximum height anterior of mid-length. Surface of each valve marked by a slightly backward pointing dorsal spine (just posterior of mid-length) and 5 distinct nodes.

Holotype. RGM 350.505

Paratype. RGM 350.506

Figs. 1-3 Amphissites urei (Jones, 1859)

Fig. 1 RGM 350.516, $560 \mathrm{~cm}, \mathrm{LV}, \mathrm{L} 0.74 \mathrm{~mm}, \mathrm{H} 0.44 \mathrm{~mm}(\mathrm{x} 100)$.

Fig. 2 RGM 350.517, $550 \mathrm{~cm}$, LV, L $0.54 \mathrm{~mm}, \mathrm{H} 0.32 \mathrm{~mm}$ (x 120).

Fig. 3a-b RGM $350.518,560 \mathrm{~cm}$, L $0.44 \mathrm{~mm}$, H $0.23 \mathrm{~mm}$ : fig. 3a, RV (x 160); fig. 3b, detail of RV (x320)

Figs. 4-5 Kirkbya quadrata Robinson 1959.

Fig. 4 RGM 350.523, $560 \mathrm{~cm} \mathrm{RV,} \mathrm{L} 0.40 \mathrm{~mm}, \mathrm{H} 0.21 \mathrm{~mm}$ (x 160).

Fig. 5a-b. RGM $350.524,540 \mathrm{~cm}, \mathrm{~L} 0.76 \mathrm{~mm}, \mathrm{H} 0.38 \mathrm{~mm}$ : fig. 5a, RV (x80); fig. 5b, detail of RV (x400). 

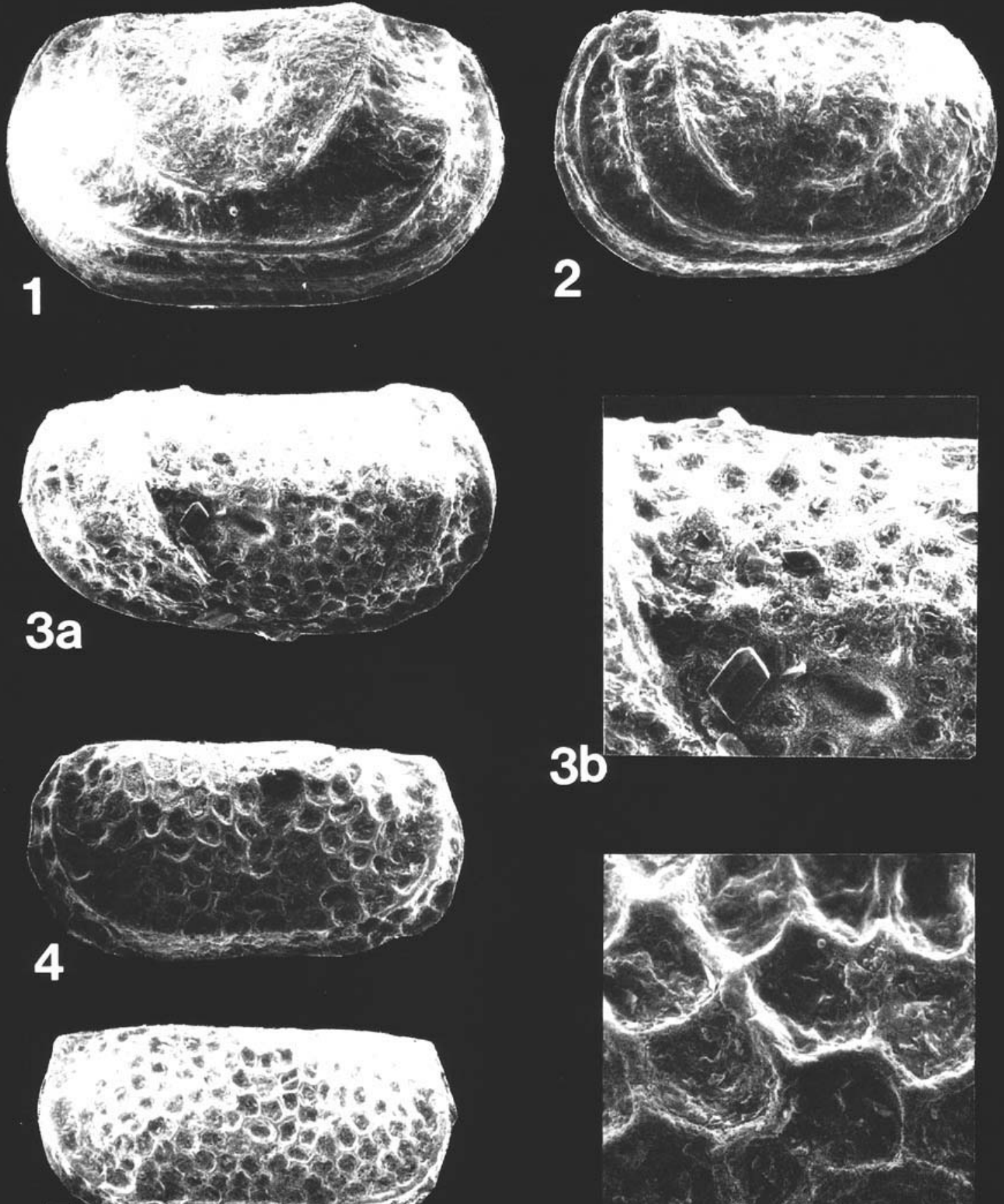

$5 a$

$5 b$

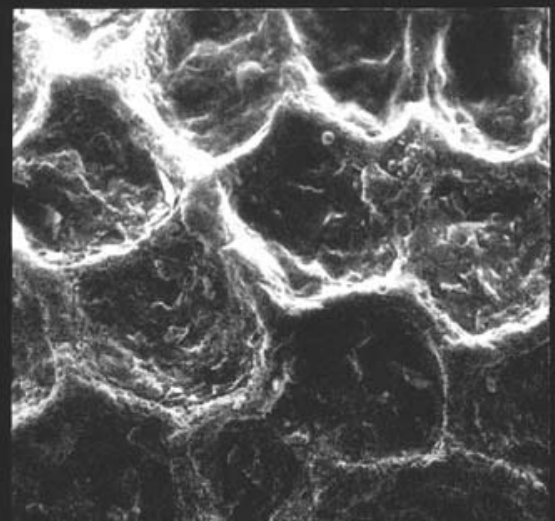


Material. Two complete carapaces.

Type locality. See Fig. 2. It corresponds to locality 55 of Moore (1958) and section 5 of Masurel (1987: fig. 1) in Bishopdale, northern England.

Description. The two specimens of this new species distinguish themselves from C. tuberculospinosa (Jones \& Kirkby, 1886 ) by a more elongated shape, due to a slightly extended posterior end. The dorsal spines are less pronounced and the reticulation pattern is variable, reticulum being relatively smaller in the posterior part, along the margins and on the nodes. The slightly swollen anterior is separated from the flattened posterior half of the carapace by a more or less distinct, narrow sulcus in front of the dorsal spine.

Remarks. The new species shows similarities in shape, presence of a median sulcus, and delicacy of the dorsal spines with $C$. tuberculospinosa var. $B$ from the Upper Mississippian Bangor Limestone formation of U.S.A., described by Devery (1987). It is distinguished from the latter by the variation in reticulation on different parts of the carapace. Furthermore it lacks the posterodorsal tubercle that marks the surface of all specimens of $C$. tuberculospinos $a$ var. $B$ (Dewey, personal communication), which, however, may be due to abrasion.

Superfamily Hollinacea Swartz, 1936

Family Hollinidae Swartz, 1936

Genus Hollinella Coryell, 1928

Hollinella (Keslingella) radiata (Jones \& Kirkby, 1886)

(Pl. 7, fig. 5)

Synonymy list and diagnosis. See Bless \& Jordan (1972, p. 54-56, Pl. 19, figs. 1-5, Pl. 20, figs. 1-7).

Material. 6 recognisable fragments of single valves.

Occurrence. Lower Carboniferous of Great Britain, Germany, U.S.S.R. and U.S.A. (Bless \& Jordan, 1972).

Genus Tetrasacculus Stewart, 1936

Tetrasacculus mirabilis (Croneis \& Gale, 1938)

(Pl. 6, figs. 3a-b, Pl. 7, fig. 1)

1938 Pterocodella mirabilis - Croneis \& Gale, p. 264-265, fig. 5.

1941 Tetrasacculus mirabilis - Cooper, p. 16, Pl. 2, figs. 12.

1978 Tetrasacculus mirabilis-Robinson, p. 130, Pl. 1, fig. 4. 1987 Tetrasacculus mirabilis - Devery, p. 83-84, Pl. 1, figs. 1-3.
Diagnosis. Carapace subovate-cuneiform in lateral view. DM straight, VM convex, ends rounded, anterior broader. Greatest height anterior, LV larger, moderately overlapping RV along free margin. Valves bilobed, with a deep curved median sulcus extending anteroventrally. Surface regularly reticulated.

Material. 4 carapaces including 2 tecnomorphs and 2 heteromorphs.

Remarks. A distinct sexual dimorphism, characteristic of this species, is found here: tecnomorphs with a small projection at the ventral end of the front lobe (Pl. 6, figs 3ab), heteromorphs with 4 anteroventral loculi (PI. 7, fig. 1). Occurrence. Asbian to Brigantian of Great Britain, Upper Mississipian of U.S.A.

Suborder Kirkbyacopina Gründel, 1969, sensu Pokorny, 1978

Superfamily Kirkbyacea Ulrich \& Bassler, 1906

Family Amphissitidae Knight, 1928 Genus Amphissites Girty, 1910

Subgenus Amphissites (Amphissites) Girty, 1910

Amphissites (Amphissites) urei (Jones, 1859)

(Fig. 5, Pl. 1, figs. 1-3)

1859 Kirkbya urei - Jones, p. 136 (not illustrated).

1870 Kirkbya urei - Jones, p. 185, Pl. 61, figs. 15a, b.

1885 Kirkbya urei - Jones \& Kirkby, p. 189, Pl. 30, fig. 19 1932 Amphissites urei - Latham, p. 369, fig. 16.

1978 Amphissites urei - Robinson, p. 144, Pl. 8, figs. la,b. 1982 Amphissites urei - Bless \& Massa, p. 27, PI. 1, fig. 5.

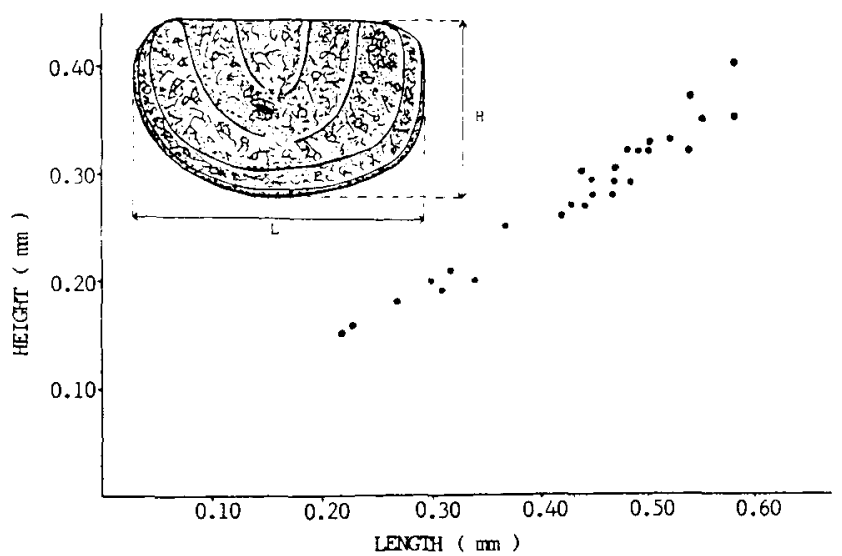

Fig. 5 Size distribution chart for 28 carapaces of Amphissites urei.

\section{Explanation of Plate 2}

Figs. 1-2 Coronakirkbya cornuta (Robinson, 1959).

Fig. la-b RGM 350.528, $560 \mathrm{~cm} \mathrm{~L} 0.56 \mathrm{~mm}$, H $0.33 \mathrm{~mm}$ : fig. la, LV (x 1220); fig. lb, detail of LV (x 400).

Fig. 2 RGM 350. 529, $560 \mathrm{~cm}, \mathrm{LV}, \mathrm{L} 0.58 \mathrm{~mm}, \mathrm{H} 0.34 \mathrm{~mm}$ (x 160)

Figs. 3-5 Scrobicula scrobiculata (Jones, Kirkby \& Brady, 1884).

Fig. 3 RGM $350.540,550 \mathrm{~cm}$, LV, L $0.53 \mathrm{~mm}$, H $0.34 \mathrm{~mm}$ (x 120).

Fig. 4 RGM $350.541,540 \mathrm{~cm}, \mathrm{RV}, \mathrm{L} 0.51 \mathrm{~mm}, \mathrm{H} 0.33 \mathrm{~mm}$ (x 120)

Fig. 5 RGM 350. $542,550 \mathrm{~cm}$, dorsal view, L $0.53 \mathrm{~mm}$, H $0.35 \mathrm{~mm}$ (x 80 ). 

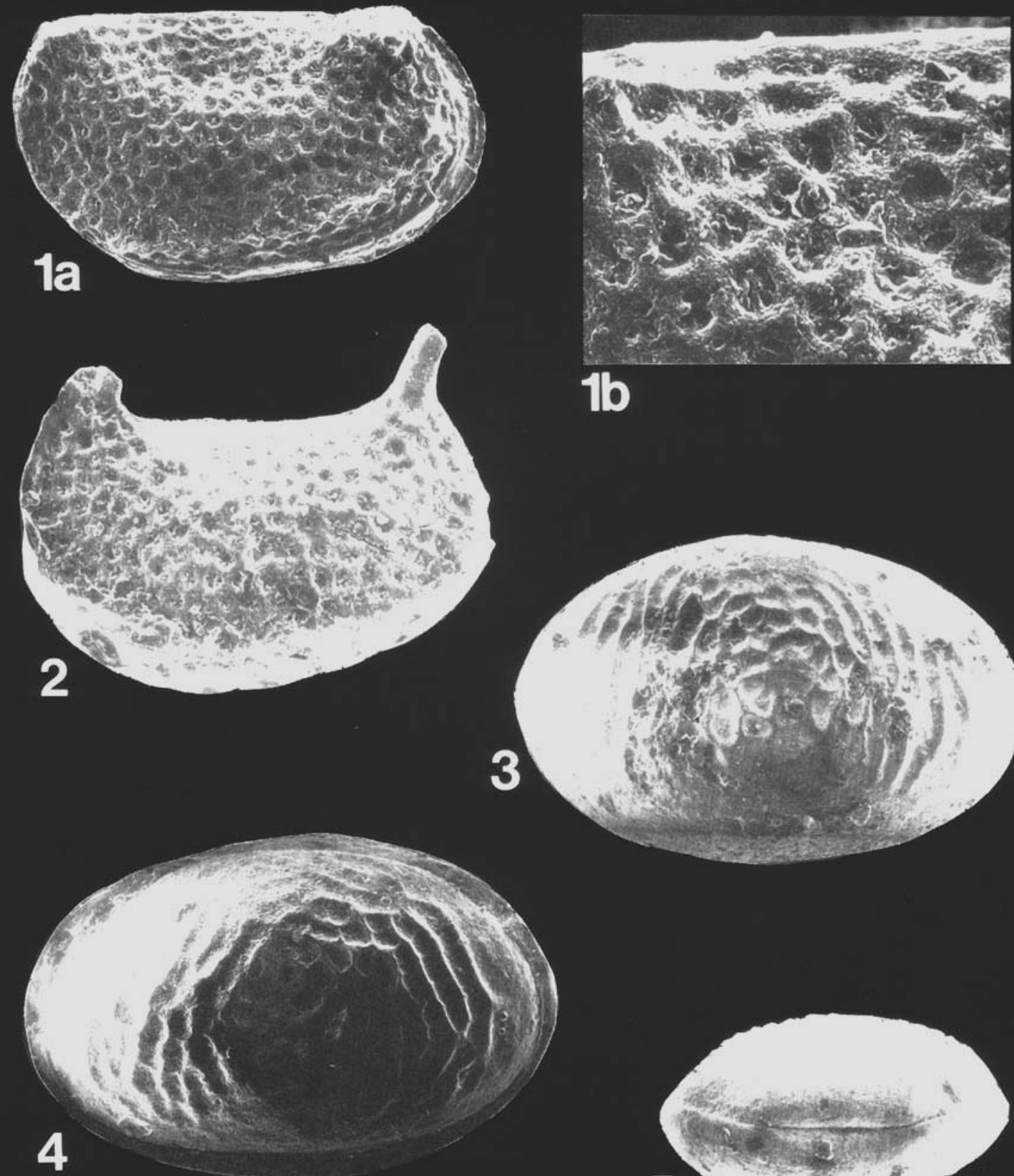

$1 b$

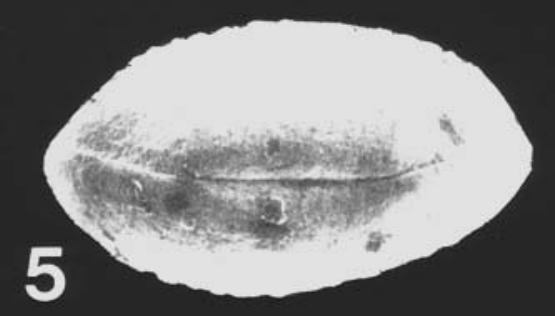


Diagnosis. Carapace oblong, rounded in lateral view, elongate subrectangular in dorsal view. Greatest length just above midline, hinge line straight. Surface reticulate, with a subcentral oval pit only observable on well preserved specimens. Three strong concentric carinae enclose an inner, more delicate $\mathrm{V}$-shaped ridge, all attached to the marginal dorsal carina.

Material. About 50 carapaces and 5 valves.

Dimensions: See Fig. 5.

Remarks. Robinson (1978) noted that a study of the variation in the pattern of the carinae, particularly the inner one (which may be U-, V- or J-shaped), might justify further subdivision.

Occurrence. Holkerian to Arnsbergian of Great Britain, Lower Carboniferous of U.S.S.R. and Upper Carboniferous of Libya.

Genus Kegelites Coryell \& Booth, 1933

Kegelites sp.

Material. 1 pyritised carapace

Description. Carapace oblong, small (L $0.25 \mathrm{~mm}, \mathrm{H} 0.15$ $\mathrm{mm}$ ), subquadrate in lateral view. Hinge line straight, ends rounded, anterior broader. VM slightly concave mediannally. Distinct marginal carina along free margin, posterior node projecting above hinge line. Surface finely reticulate.

Superfamily Kirkbyacea Ulrich \& Bassler, 1906

Family Kirkbyidae Ulrich \& Bassler, 1906

Genus Kirkbya Jones, 1859

Kirkbya quadrata Robinson, 1959

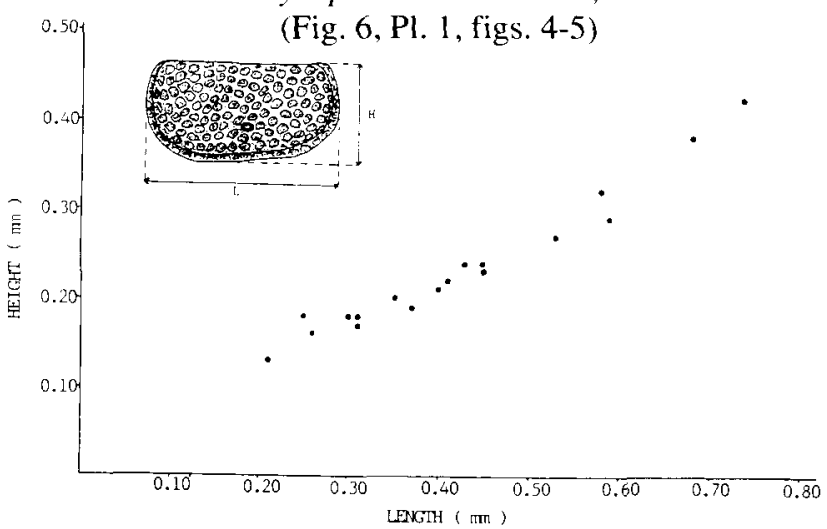

Fig. 6 Size distribution chart for 18 carapaces of Kirkby quadrata.
1959 Kirkbya quadrata - Robinson, p. 437, Fig. 2: 4-5 1978 Kirkbya quadrata - Robinson, p. 142, Pl. 7, figs. 4a,b. Diagnosis. Carapace quadrate in lateral outline, DM and VM almost straight. Elongate subrectangular in dorsal view, hinge line straight. Greatest length just above midline, valves subequal, slightly higher behind than in front. Surface regularly reticulated, reticulum being fairly large, with a subcentral kirkbyan pit and 2 marginal rims.

Material. About 40 carapaces and 8 valves.

Dimensions. See fig. 6 .

Remarks. Many specimens are flattened and more or less distorted, due to compression in the sediment.

Occurrence: Upper Brigantian of Great Britain.

Genus Coronakirkbya Sohn, 1954

Coronakirkbya cornuta (Robinson, 1978)

(Pl. 2, figs. 1-2)

1978 ?Coronakirkbya cornuta-Robinson, p. 142, Pl. 7, figs. la-b.

Diagnosis. Carapace semicircular in lateral view, maximum height posterior of midline. DM straight, VM and ends rounded, cardinal angles obtuse. Two hollow spines rise from the cardinal angles, pointing slightly backwards. A central lobe is more or less strongly developed, carrying a kirkbyan pit. The inner of the two marginal carinae is somewhat irregular to the outline. Surface finely reticulate. Material. 2 carapaces with damaged spines.

Remarks. The specimens described in this paper closely resemble ?Kirkbya cornuta illustrated by Robinson (1978, Pl. 7, figs. la,b). Robinson assigned his specimens with some doubt to the genus Kirkbya, because of the absence of a distinct central lobe. Nevertheless, it is suggested here that the central lobe, which is a diagnostic feature of Coronakirkbya, may sometimes be obscured by abrasion or may be less well developed, as illustrated by the specimens described in this paper. Other species of Coronakirkbya also often show some variation in the prominence of the central lobe, e.g. C. krejcigrafi from the Upper Carboniferous of N. Spain (Becker, 1978: p. 57-58, Pl. 4, figs. 19-22).

Family Roundyellidae Gramm, 1976

Genus Roundyella Bradfield, 1935

Roundyella binoda sp. nov.

(Fig. 7, Pl. 1, figs. 1-5)

\section{Explanation of Plate 3}

Figs. 1-5 Roundyella binoda $\mathrm{n}$. sp.

Fig. 1 RGM 350. 530, holotype, $500 \mathrm{~cm}, \mathrm{LV}, \mathrm{L} 0.45 \mathrm{~mm}, \mathrm{H} 0.25 \mathrm{~mm}$ (x 140).

Fig. 2 RGM 350. 531, paratype, $500 \mathrm{~cm}$, dorsal view, L $0.38 \mathrm{~mm}, \mathrm{H} 0.22 \mathrm{~mm}$ (x 140).

Figs. 3a-b RGM 350. 532, paratype, $560 \mathrm{~cm}, \mathrm{~L} 0.41 \mathrm{~mm}, \mathrm{H} 0.26 \mathrm{~mm}$ : fig. 3a, LV (x 140); fig. 3b, detail of LV (x 400).

Fig. 4 RGM 350. 533, $540 \mathrm{~cm}$, RV, L $0.42 \mathrm{~mm}, \mathrm{H} 0.25 \mathrm{~mm}$ (x 140).

Fig. 5 RGM 350. 534, $540 \mathrm{~cm}$, RV, L $0.40 \mathrm{~mm}, \mathrm{H} 0.25 \mathrm{~mm}$ (x 140).

Figs. 6a-b Eriella minima n. sp., RGM 350.635 , holotype, $200 \mathrm{~cm}, \mathrm{~L} 0.44 \mathrm{~mm}, \mathrm{H} 0.25 \mathrm{~mm}$ : fig. $6 \mathrm{a}$, LV (x 160); fig. 6b, detail of LV (x 320) 


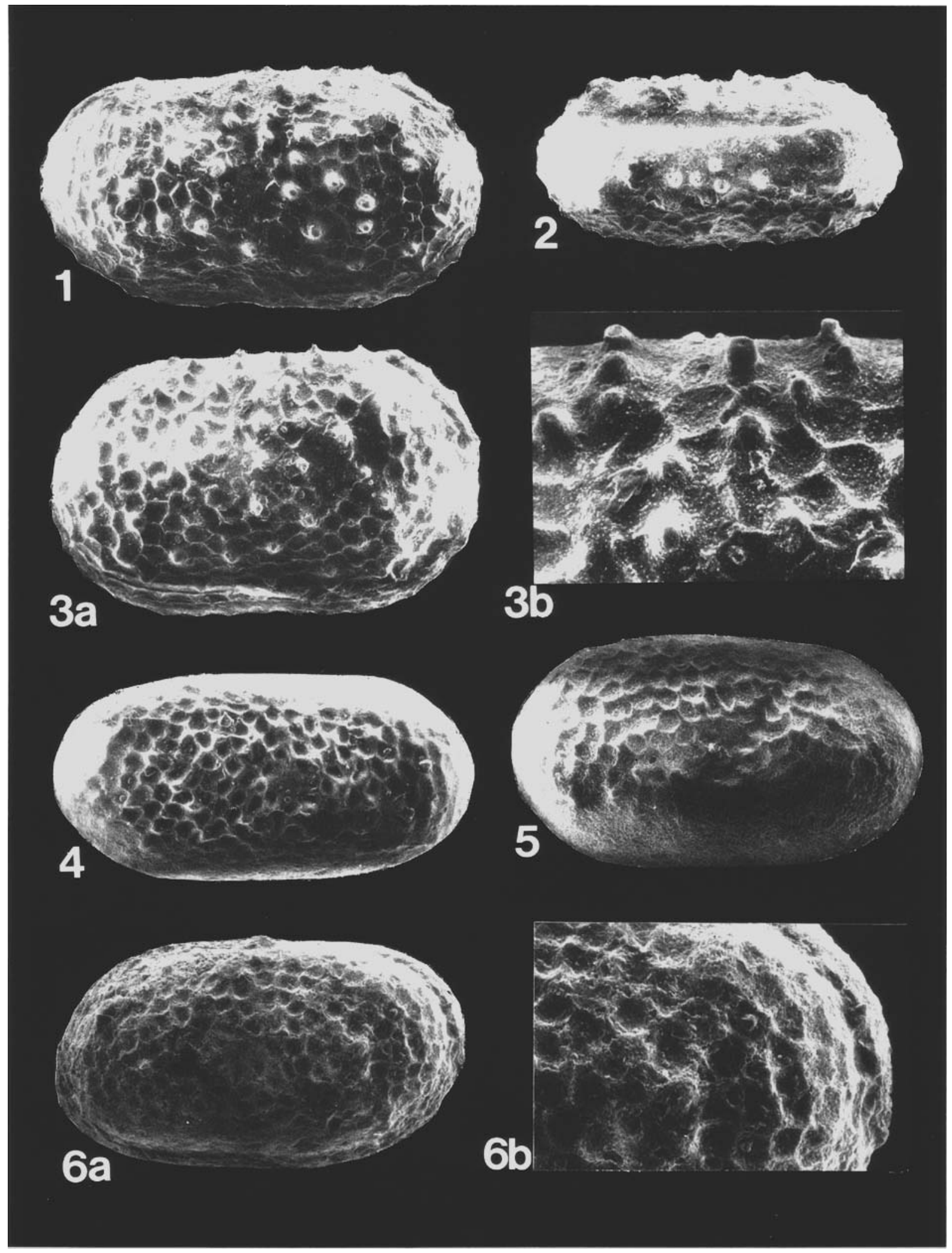


Derivation of name. Latin, referring to the presence of 2 node-like posterodorsal spines.

Diagnosis. Carapace oblong, subquadrate in lateral outline. DM straight, VM Straight or slightly concave, ends almost equally rounded. Inequivalved, RV overlapping LV. Hinge line straight, hinge slightly impressed. Surface ornamented with a regular reticulation and scattered spines/papillae, and a small but distinct node-like spine in the posterodorsal area of each valve, a subcentral smooth muscle spot.

Holotype. RGM 350.530 (PI. 1, fig. 1)

Paratypes. RGM 350.531, 350. 532 (Pl. 1, figs. 2, 3).

Material. More than 150 carapaces.

Type locality. See fig. 2. It corresponds to locality 55 of Moore (1958) and section 5 of Masurel (1987: fig. 1) in Bishopdale, northern England.

Dimensions. See fig. 7.

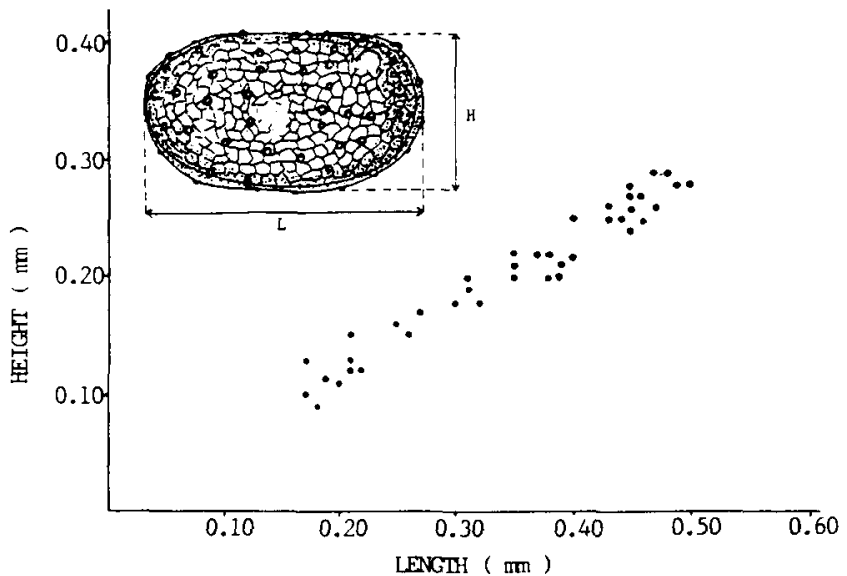

Fig. 7 Size distribution chart for 40 carapaces of Roundyella binoda n. sp.

Remarks. This new species has similarities in shape and surface ornament to $R$. reticulosa (Jones \& Kirkby, 1886) and $R$. simplicissima (Knight, 1928). It is distinguished by the presence of two relatively larger posterodorsal spines observable in dorsal view (Pl. 1, fig. 2), and which are already prominent in early instars. $R$. dorsopapillosa Sohn $(1954, \mathrm{p}$. 19, Pl. 1, figs. 20-26) is another species with posterodorsal spines. The latter is considerably larger and has a greater number of spines scattered on the surface.
Family Scrobiculidae Posner, 1951

Genus Scrobicula Posner, 1951

Scrobicula scrobiculata (Jones, Kirkby \& Brady, 1884)

(Fig. 8, PI. 2, figs. 4-6)

1884 Cytherella scrobiculata - Jones, Kirkby \& Brady, 1884, P. 76-77, Pl. 6, fig. 10.

1951 Scrobicula scrobiculata - Posner, p. 53, PI. 10, fig. 3. 1978 Scrobicula scrobiculata - Robinson p. 148, Pl. 10, figs. $3 a, b$.

Diagnosis. Carapace oval-oblong, ends almost equally rounded. Inequivalved, LV overlapping RV. Hinge line straight, hinge slightly impressed. Surface ornamented with a strong "fingerprint" reticulation, relatively longer meshes tend to be concentric.

Material. About 100 carapaces.

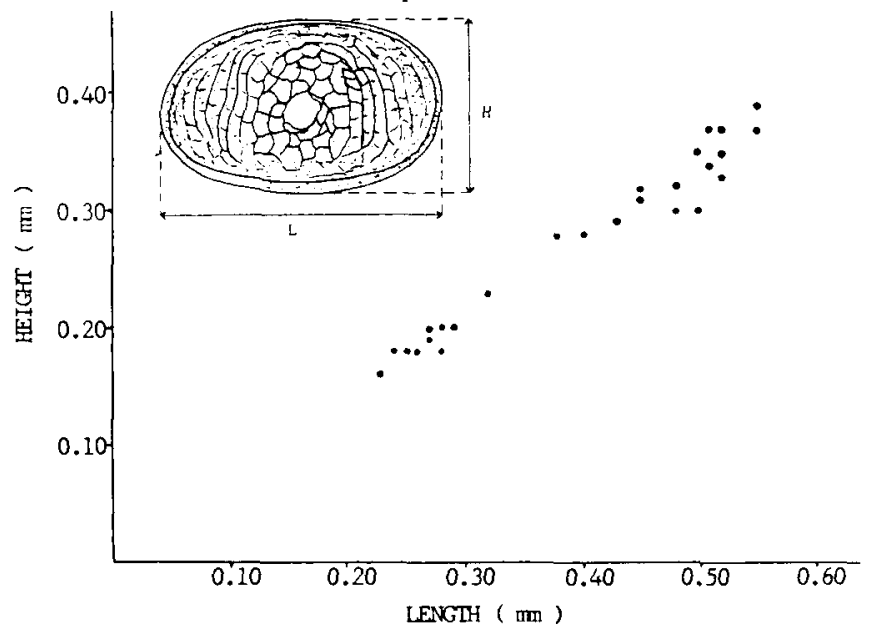

Fig. 8 Size distribution chart for 26 carapaces of Scrobicula scrobiculata.

Dimensions. See fig. 8

Remarks. A study of variations in the reticulate pattern of this species might lead to further subdivision.

Occurrence: Brigantian of Great Britain, Lower Carboniferous of U.S.S.R.

Superfamily Primitiopsacea Swartz, 1939

Family Graviidae Polenova, 1952

Genus Coryellina Bradfield, 1935

Coryellina cf. reticosa (Jones \& Kirkby, 1886)

(Pl. 7, fig. 2)

\section{Explanation of Plate 4}

Figs. 1-4 Cribroconcha caneyensis (Harlton, 1927).

Fig. 1. RGM $350.582,550 \mathrm{~cm}, \mathrm{LV}, \mathrm{L} 0.60 \mathrm{~mm}, \mathrm{H} 0.33 \mathrm{~mm}$ (x 120)

Fig. 2 RGM $350.583,550 \mathrm{~cm}$, RV, interior, L $0.59 \mathrm{~mm}, \mathrm{H} 0.35 \mathrm{~mm}$ (x 120).

Fig. 3 RGM 350. 584, $25 \mathrm{~cm} \mathrm{RV,} \mathrm{L} 0.63 \mathrm{~mm}, \mathrm{H} 0.38 \mathrm{~mm}$ (x 120).

Fig. 4 RGM 350. 585, $25 \mathrm{~cm}$, dorsal view, L $0.59 \mathrm{~mm}, \mathrm{H} 0.35 \mathrm{~mm}$ (x 120).

Figs. 5-8 Cribroconcha insculpta Robinson 1959.

Fig. 5 RGM 350. 572, $25 \mathrm{~cm}$, RV, L $0.50 \mathrm{~mm}$, H $0.22 \mathrm{~mm}$ (x 140).

Fig. 6 RGM 350. 573, $550 \mathrm{~cm}$, dorsal view, L $0.51 \mathrm{~mm}, \mathrm{H} 0.23 \mathrm{~mm}$ (x 120).

Fig. 7 RGM $350.574,540 \mathrm{~cm}$, LV, L $0.50 \mathrm{~mm}, \mathrm{H} 0.28 \mathrm{~mm}$ (x 120).

Fig. 8 RGM $350.575,540 \mathrm{~cm}$, RV slightly oblique, L $0.51 \mathrm{~mm}, \mathrm{H} 0.23 \mathrm{~mm}$ (x I20). 


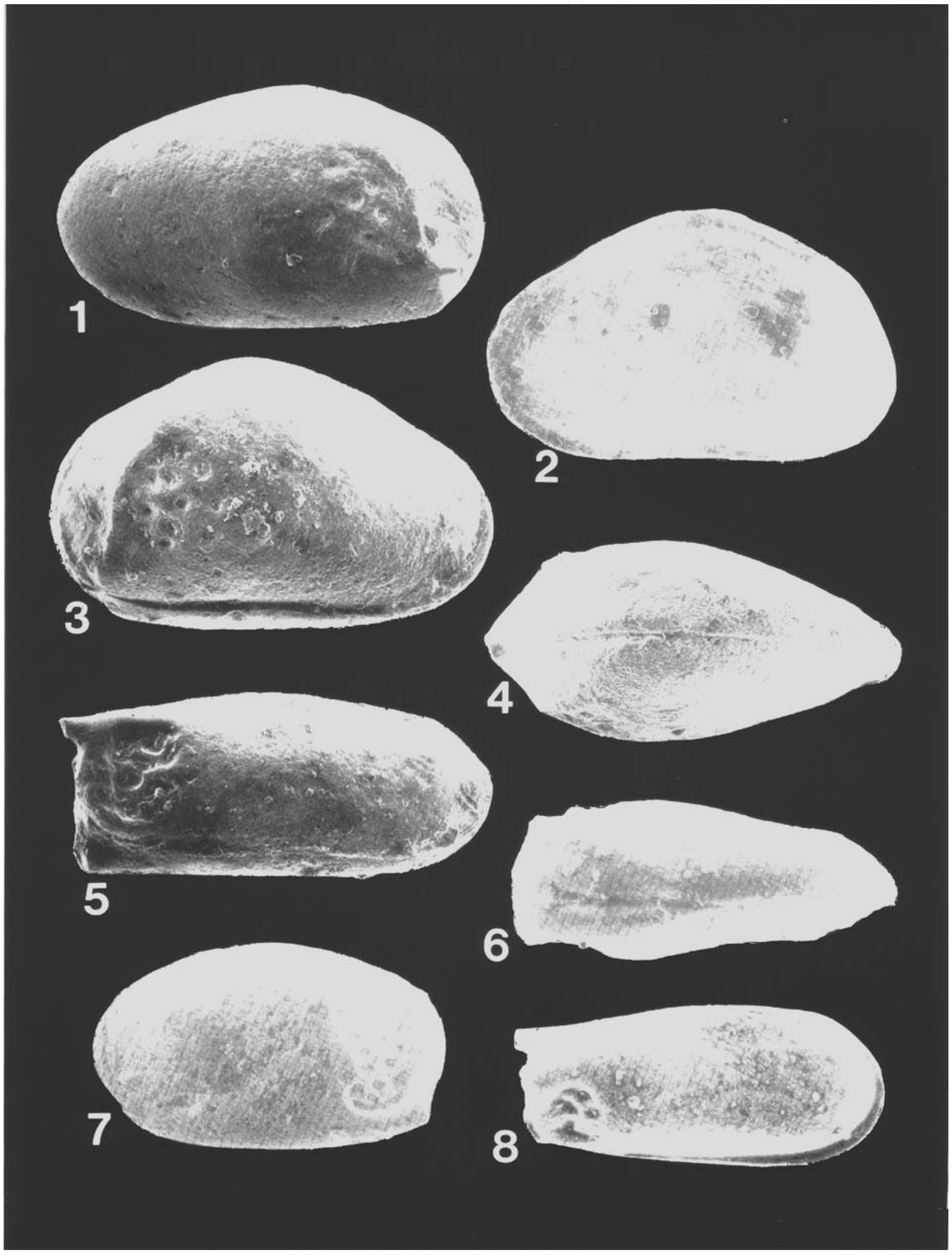


Diagnosis. Carapace obliquely subovate in lateral outline. DM straight, VM arched, ends rounded, posterior broader. Valves almost equal, RV larger. Surface regularly reticulate, median sulcus anterior of mid-length.

Material. 1 carapace.

Description. A deep median sulcus marks the finely reticulate surface, with an obscure node behind and a more clearly developed lobe in front of the sulcus. Small spines are scattered in the posteroventral area, and there is a larger posteroventral spine (broken off in the material examined). Remarks. Robinson (1978) described this species from the Pendleian of Great Britain, and illustrated it with a specimen with a slightly weaker median sulcus.

Occurrence. C. reticosa is recorded from the Pendleian to lower-most Arnsbergian of Great Britain (Robinson, 1978).

Suborder Kirkbyocopina?

Superfamily Youngiellacea Kellet, 1933

Family Youngiellidae Kellet, 1933

Genus Moorites Coryell \& Billings, 1932

Moorites elongatus (Jones \& Kirkby, 1886)

Pl. 7, fig. 6

1886 Cytherella (?) elongata - Jones \& Kirkby, p. 262-263, P1. 9, figs. 2-3.

1941 Moorites elongatus - Cooper, p. 20, Pl. 1., figs. 3a-b. Diagnosis. Carapace elongate, slightly oblique in lateral view. Max imum height anteriorly, ends rounded. DM straight and long, VM straight or flatly convex. LV larger, moderately overlapping along the entire margin. Marginal rims obscure, most prominent along the anterior end.

Material. 5 carapaces.

Description. See diagnosis. Pits have been detected in undefined depressions bordering the anterior and more obscure posterior marginal rim, and scattered on the rest of the surface. The marginal rim, particularly the anterior, appears to have been best developed in the adult stages.

Occurrence. Lower Carboniferous of Great Britain.

Order Myodocopida Sars, 1866

Suborder Cladocopina Sars, 1866

Family Polycopidae Sars, 1866

Genus Discoidella Croneis \& Gale, 1939 Discoidella $\mathrm{sp}$.

? 1959 Discoidella cf. convexa - Robinson, p. 437, fig. 2: 1-
2.

Material. 6 poorly preserved carapaces.

Diagnosis: Carapace subcircular in lateral view, greatest width above mid-height. Hinge short, straight and depressed below DM. Surface ornamented by very faint concentric striae, more or less parallel to the free margin.

Order Metacopida Sylvester-Bradley, 1961

Superfamily Healdiacea Harlton, 1934

Family Healdiidae Harlton, 1933

Genus Cribroconcha Cooper, 1941

Cribroconcha caneyensis (Harlton, 1927)

(Fig. 9, Pl. 4, figs. 1-4.)

1927 Healdia caneyensis - Harlton, p. 207, fig. 3.

1947 Healdia caneyensis - Cooper, PI. 22, figs. 5-7.

? 1977 Healdia ex gr.H. caneyensis - Sohn, p. 150, Pl. 2, figs. 4-5

Diagnosis. Carapace subovate to subtriangular in lateral view, maximum height posterior, maximum width central. LV overlapping RV along the entire margin. DM arched, VM almost straight, ends rounded, anterior narrower. Posteriorly, a curved, almost vertical posterior ridge, concave anteriorly, is terminated both dorsally and ventrally by small, posteriorly directed spines. A slightly depressed pit-field with scattered circular pits borders the inner, anterior side of the ridge. Otherwise smooth.

Material. About 100 carapaces and 15 valves. Dimensions. See Fig. 9.

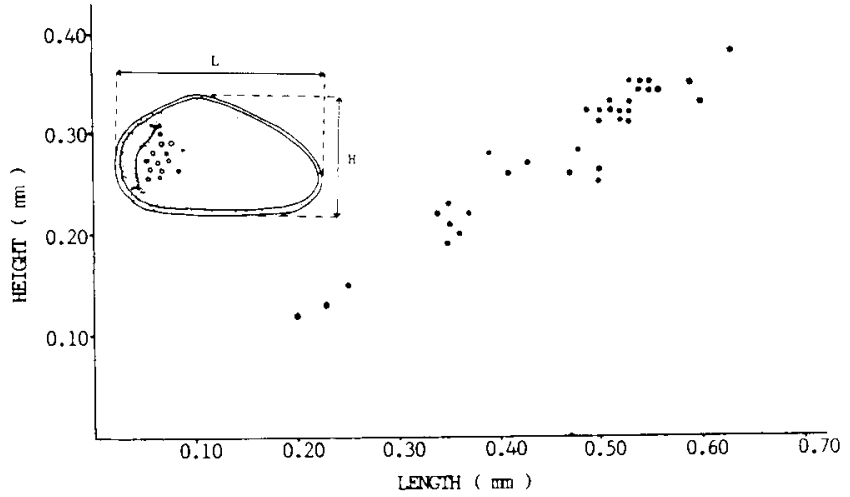

Fig. 9 Size distribution chart for 35 carapaces of Cribroconcha caneyensis.

\section{Explanation of Plate 5}

Figs 1-2 Cribroconcha perplexa Robinson 1959.

Fig. 1 RGM 350.576, $920 \mathrm{~cm}$, RV, L $0.65 \mathrm{~mm}, \mathrm{H} 0.33 \mathrm{~mm}$ (120).

Fig. 2 RGM 350. $577,920 \mathrm{~cm}$, RV, L $0.68 \mathrm{~mm}, \mathrm{H} 0.35 \mathrm{~mm}$ (x 100).

Figs 3-7 Healdianella cf. darwinuloides Posner, 1951.

Fig. 3 RGM 350. 593, $25 \mathrm{~cm} \mathrm{RV,} \mathrm{L} 0.42 \mathrm{~mm}$, H $0.22 \mathrm{~mm}$, tecnomorph ( 200 ).

Fig. 4 RGM 350. 594, $200 \mathrm{~cm}$, RV, L $0.43 \mathrm{~mm}, \mathrm{H} 0.25 \mathrm{~mm}$, tecnomorph (x 160).

Figs. 5a-b. RGM 350. 595, $190 \mathrm{~cm}$, L $0.46 \mathrm{~mm}, \mathrm{H} 0.23 \mathrm{~mm}$, tecnomorph: fig. 5a, RV (x 160); fig. 5b, detail of RV (x 400).

Fig. 6 RGM $350.596,560 \mathrm{~cm}$, heteromorph, LV, L $0.61 \mathrm{~mm}, \mathrm{H} 0.33 \mathrm{~mm}$ (x 120).

Fig. 7 RGM $350.597,550 \mathrm{~cm}$ heteromorph, RV. L $0.62 \mathrm{~mm}, \mathrm{H} 0.36 \mathrm{~mm}$ (x 120$)$. 


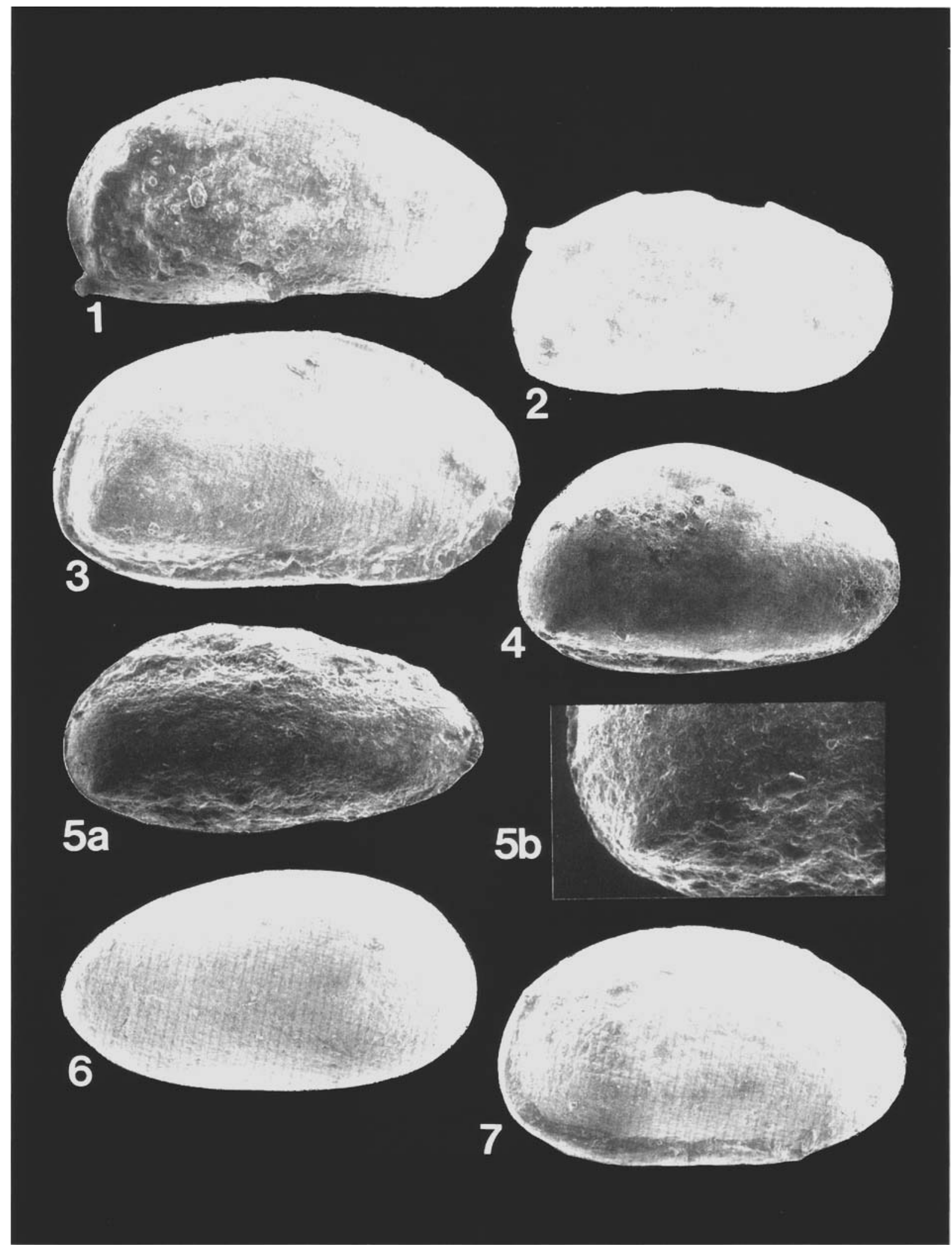


Remarks. The assignment of this species to the genus Cribroconcha is based on the presence of a pit-field anterior of the posterior ridge (Sylvester-Bradley in Moore, 1961, p. 361). It is probably conspecific with Healdia sp. ex $\mathrm{gr}$. H. caneyensis recorded from the Upper Mississipian of northern Arkansas (Sohn, 1977). The latter only differs in that the posterior ridge is straight which may be a geographic variation.

Occurrence. So far only recorded from the Upper Mississippian of U.S.A., this is the first record from Great Britain.

\section{Cribroconcha insculpta Robinson, 1959}

(Fig. 10, Pl. 4, figs. 5-8)

1959 Cribroconcha? insculpta - Robinson, p. 443,

Fig. 1: 4a-c.

1978 Cribroconcha insculpta - Robinson, p. 144, Pl. 8, figs. $3 a, b$.

Diagnosis. Carapace elongate in lateral and dorsal view, DM convex, VM straight or slightly convex. Greatest height central, greatest width posterior of midline. Inequivalved, LV overlapping RV. Surface smooth, marked by a vertical posterior ridge which is concave anteriorly. A coarsely pitted, reticulated depression borders the inner, anterior side of the ridge, which is terminated both dorsally and ventrally by strong, backward-produced spines.

Material. 35 carapaces.

Dimensions. See fig. 10.

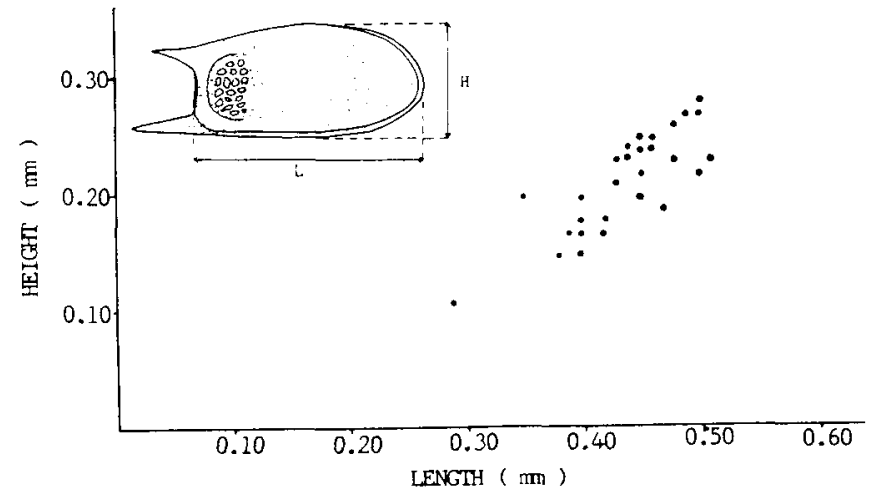

Fig. 10 Size distribution chart for 29 carapaces of Cribroconcha insculpta.

Remarks. Cribroconcha insculpta shows some variation in the length/height ratio (fig. 10), which is ascribed to sexual dimorphism: The first form, characterised by a greater height and a more symmetrically convex dorsal outline ( $\mathrm{Pl}$. 10, fig. 7), and the second, relatively lower form with the greatest thickness posterior of mid-length (Pl. 10, figs. 5, 6 an 8 ), are respectively interpreted as female and male.

Occurrence. Brigantian of Great Britain.

Cribroconcha perplexa Robinson, 1959

(Pl. 5, figs. 1-2.)

1959 Cribroconcha perplexa - Robinson, p. 442,

Fig. 1: 3a-c.

1978 Cribroconcha perplexa - Robinson, p. 144, Pl. 8, figs. $5 a, b$.

Diagnosis. Carapace elongate, DM convex, VM slightly concave. Ends rounded, anterior narrower, maximum height and width central. Surface smooth, marked by an anterior marginal flange and a vertical ridge near the posterior margin of each valve. The ridge is concave anteriorly, with two backward pointing spines at the dorsal and ventral ends. The ventral spine points slightly downwards, the dorsal slightly upwards. A pit-field with small, irregularly spaced pits borders the anterior side of the ridge.

Material. 5 carapaces and 6 partly damaged valves.

Occurrence. Brigantian of Great Britain.

Genus Healdianella Posner, 1951

Healdianella cf. darwinuloides Posner, 1951

(Fig. 11, Pl. 5, figs. 3-7.)

Diagnosis. Carapace elongate-ovate to subtriangular in lateral view. Maximum height and width at, or just posterior of mid-length. DM convex, VM straight or slightly convex. LV larger, overlapping RV. Surface generally smooth, occasional faint reticulation at posterior.

Material. 45 carapaces and 2 valves.

Dimensions. See fig. 11.

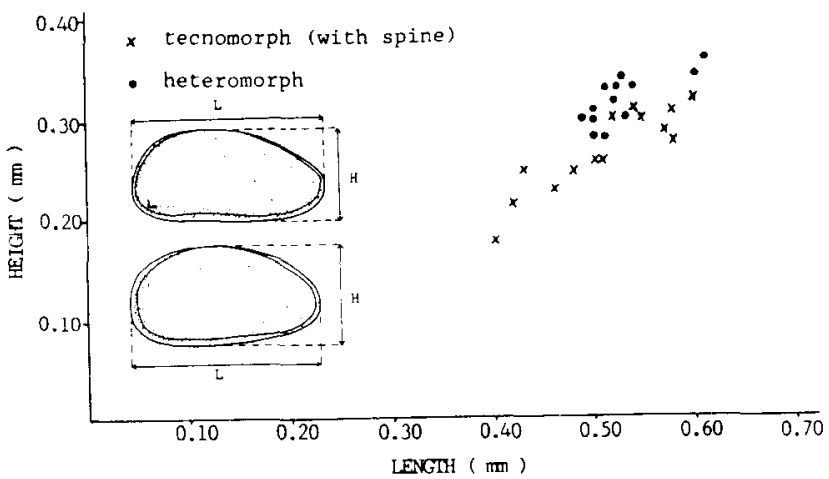

Fig. 11 Size distribution chart for 27 carapaces of Healdianella cf. darwinuloides.

\section{Explanation of Plate 6}

Figs la-b Cornigella posteroextensa n. sp., RGM 350. 505, holotype, $540 \mathrm{~cm}, \mathrm{~L} 0.59 \mathrm{~mm}, \mathrm{H} 0.30 \mathrm{~mm}$ : fig. la, LV (x 160); fig. $1 \mathrm{~b}$, detail of LV (x 400).

Figs 2a-b Cornigella tuberculospinosa (Jones \& Kirkby, 1886), RGM 350. 501, $500 \mathrm{~cm}, \mathrm{~L} 0.49 \mathrm{~mm}, \mathrm{H} 0.32 \mathrm{~mm}$ : fig. 2a, RV (x 120); fig. 2b, detail of RV (x 240).

Figs. 3a-b Tetrasacculus mirabilis (Cronies \& Galke, 1938), RGM 350.512, $540 \mathrm{~cm}, \mathrm{~L} 0.65 \mathrm{~mm}, \mathrm{H} 0.32 \mathrm{~mm}$ tecnomorph: fig. 3a. LV (x 100); fig. 3b, detail of LV (x 200). 

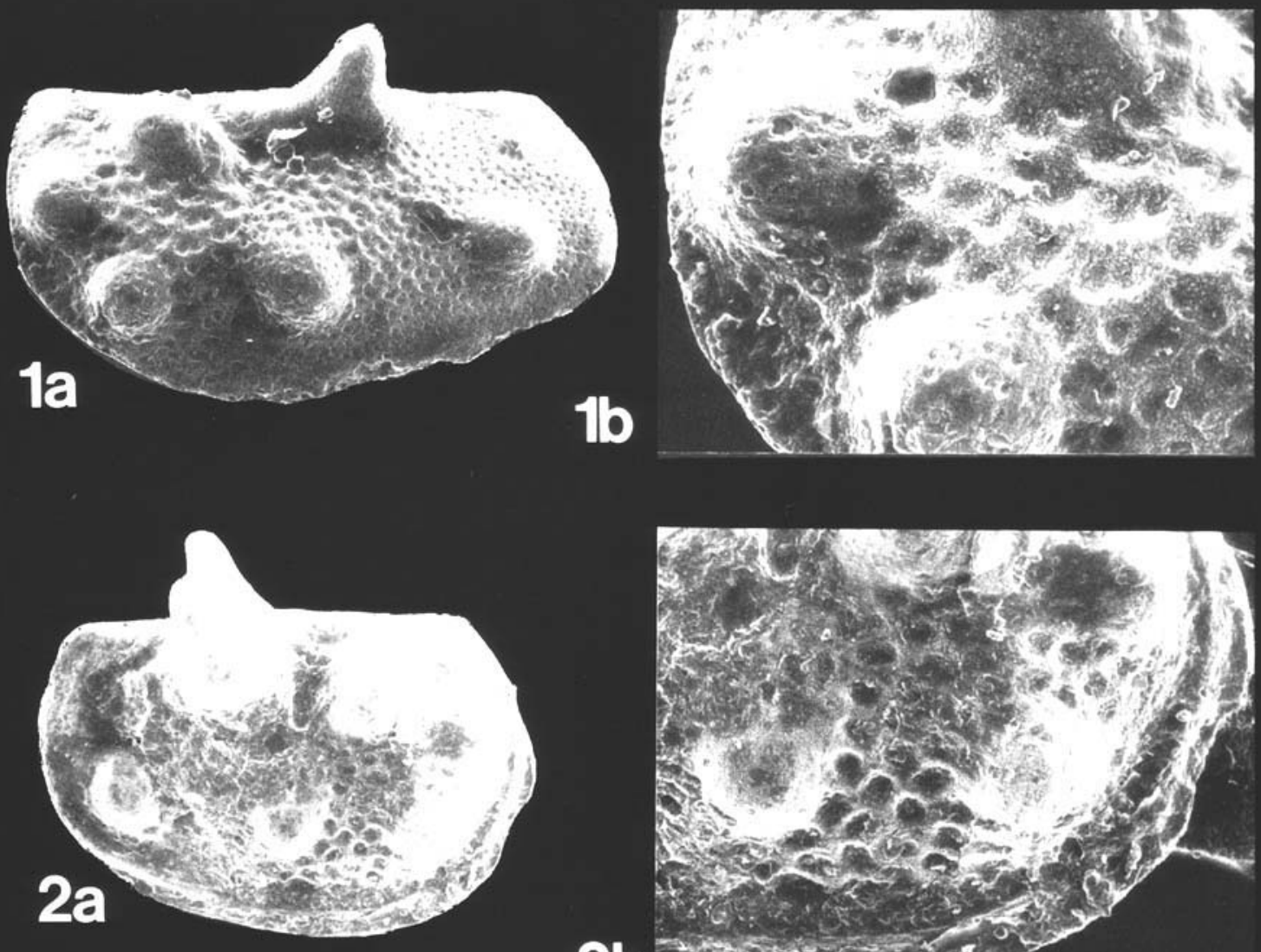

$2 b$ ecsents

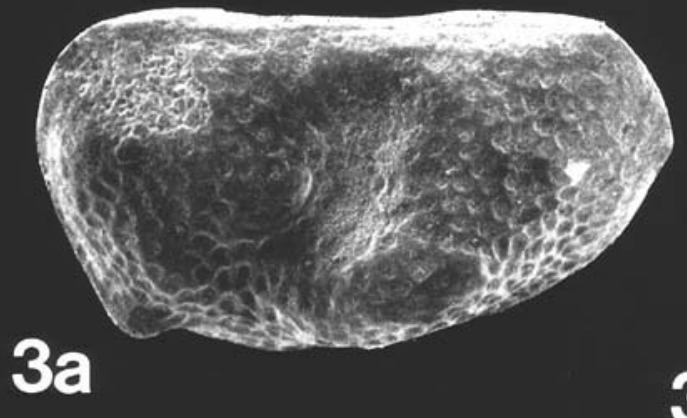

3b

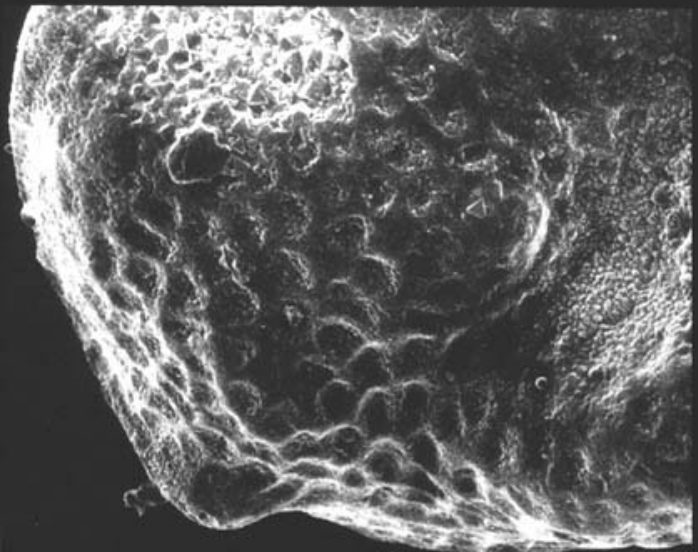


Remarks. The lenticular and transversely stretched meshes of the reticulation pattern, which is sometimes visible in the posterior area, are similar to those illustrated by Gramm 1982, Pl. 2, fig. 7, Pl. 3, fig. 4). This author suggested that in a related species ("Healdia cornuta" Posner, 1951) the posteroventral spine, which is usually found on right valves only, may be a larval adaption that is sometimes retained into the adult stage. In this study, the presence of a posteroventral spine is confined to early instars and males (tecnomorphs), which are distinguished from females (heteromorphs) by a less symmetrically rounded, generally more elongated shape (fig. 11). The tecnomorphs illustrated in Plate 5, figs. 3-5, resemble Healdianella darwinuloides Posner (Gramm, personal communication).

The subcircular adductor muscle scar is sometimes faintly visible just to the postero-ventral of centre.

Occurrence. Healdianella darwinuloides has been recorded from Visean strata of U.S.S.R. (Posner, 1951; Gramm, 1982). Species with affinities have been described from the Visean of France (Crasquin, 1987, Pl. 11, figs. 9a,b) and Mississipian of U.S.A. (Dewey, 1987, Pl. 6, figs. 9-11).

Order Podocopina Muller, 1894

Suborder Bairdiocopina Gründel, 1967 (sensu 1978)

Superfamily Bairdiacea Sars, 1888

Family Bairdiidae Sars, 1888

Subfamily Bairdiinae Sars, 1888

Genus Bairdiacypris Bradfield, 1935

Bairdiacypris subelongata (Jones \& Kirkby, 1879)

(Pl. 8, figs. 6-7)

1879 Bairdia subelongata - Jones \& Kirkby, p. 573, Pl. 30, Figs. 1-5

1960 Bairdiacypris subelongata - Sohn, p. 59.

Diagnosis: Carapace elongate, DM and VM subparallel, DM convex, VM almost straight. LV larger, overlapping along free margin. Posterodorsal slope slightly concave, ending in a blunt posterior end below mid-height. Anterior end broadly rounded. Surface smooth.

Material. 9 carapaces and 23 recognisable fragments.

Remarks. Jones \& Kirkby $(1886,1892)$ and other authors, e.g. Vine (1884) and Harlton (1927, 1929) have assigned different species to $B$. subelongata (see Sohn, 1960, p.59)

Occurrence. Carboniferous of Great Britain.

Bairdiacypris sp. aff. B. rohusta Kummerow, 1939 (Pl. 8. fig. 5.)

Diagnosis. Carapace elongate, subrectangular in lateral view. DM gently convex, VM sharply concave. Ends broadly rounded, maximum width posterior to mid-length. LV larger, overlapping RV. Surface smooth.

Materials. 1 carapace.

Occurrence. The specimen shows affinities to Bairdiacypris aff. rohusta described from Lower Tournaisian strata of Belgium (Becker \& Bless, 1974) and late Dinantian Carbonates of N. Belgium (Bless et al., 1981), and $B$. quasielongata Bushmina, 1968 from the Tournaisian of U.S.S.R. (Bless et at., 1981, p. 150, Pl. 3, figs. 55-57.

\section{Bairdiacypris cf. curvis (Cooper, 1941)}

Diagnosis. Carapace small, elongate, Concavity of VM distinct, slightly anterior to mid-length. DM gently convex, ends rounded. Surface smooth.

Material. 1 poorly preserved carapace.

Occurrence. Bairdiacypris curvis has been recorded from the Upper Mississippian of U.S.A. (Cooper, 1941, p. 25, Pl. 1, figs. 43-44; Sohn, 1960, p. 58, Pl. 2, figs. 11-13).

Genus Bairdia McCoy, 1844

Bairdia beedei Ulrich \& Bassler, 1906

$$
\text { (P1. 9, fig. 5) }
$$

1906 Bairdia beedei - Ulrich \& Bassler, p. 161, Pl. 11, figs. 19-20.

Diagnosis. Carapace subelongate, dorsum convex, venter almost straight. Posterior end acuminate, anterior end broadly rounded above mid-length. LV larger, moderately overlapping $\mathrm{RV}$ along the entire margin. Anteroventral margin gently convex, anterodorsal margin straight. Posteroventral margin slightly convex, posterodorsal margin more strongly convex. Dorsal outline ovate, sides evenly rounded, sloping towards anterior and posterior ends. Surface pitted.

Material. 2 carapaces and 1 valve.

Occurrence. Lower Pennsylvanian to Permian of U.S.A. (Sohn, 1960); Pendleian to Amsbergian of Great Britain (Robinson, 1978). This is the first record from strata older than Pendleian. See Sohn (1960, p. 23) for full synonymy.

$$
\begin{aligned}
& \text { Bairdia harltoni Cooper, } 1946 \\
& \text { (Pl. 9, figs. 7-8.) }
\end{aligned}
$$

1946 Bairdia harltoni - Cooper, p. 45, Pl. 2, figs. 30-31.

(For synonymy list see Sohn, 1960, p. 27).

Diagnosis. Carapace subdeltoid in lateral view, dorsum boldly convex, venter straight or slightly convex. Sinuous antero- and posterodorsal margins, anterior margin with

\section{Explanation of Plate 7}

Figs. 1a-b Tetrasacculus mirabilis (Croneis \& Gale, 1938), RGM 350. 514, $25 \mathrm{~cm}, \mathrm{~L} 0.67 \mathrm{~mm}, \mathrm{H} 0.38 \mathrm{~mm}$ heteromorph: fig. la, RV (x 100); fig. 1b, detail of RV (x 240).

Fig. 2 Coryellina cf. reticosa (Jones \& Kirkby, 1886), RGM 350. 547, $870 \mathrm{~cm}$, LV L $0.82 \mathrm{~mm}, \mathrm{H} 0.49 \mathrm{~mm}$ (x 80).

Fig. 3 Shishaella cf. williamsae Sohn, 1971, RGM 350.630, $870 \mathrm{~cm}$, LV L $0.57 \mathrm{~mm} \mathrm{H} 0.42 \mathrm{~mm}$ (x 100).

Fig. 4 Shivaella armstrongiana (Jones \& Kirkby, 1886), RGM 350. 634, $895 \mathrm{~cm}$, LV L 0.98 mm, H $0.65 \mathrm{~mm}$ (x 80).

Fig. 5 Hollinella radiata (Jones \& Kirkby, 1886), RGM $350.511,560 \mathrm{~cm}$, fragment of RV (x 60).

Fig. 6 Moorites elongatus (Jones \& Kirkby, 1886), RGm 350, 548, $540 \mathrm{~cm}, \mathrm{RV}, \mathrm{L} 0.39 \mathrm{~mm}, \mathrm{H} 0.17 \mathrm{~mm}$ ). 


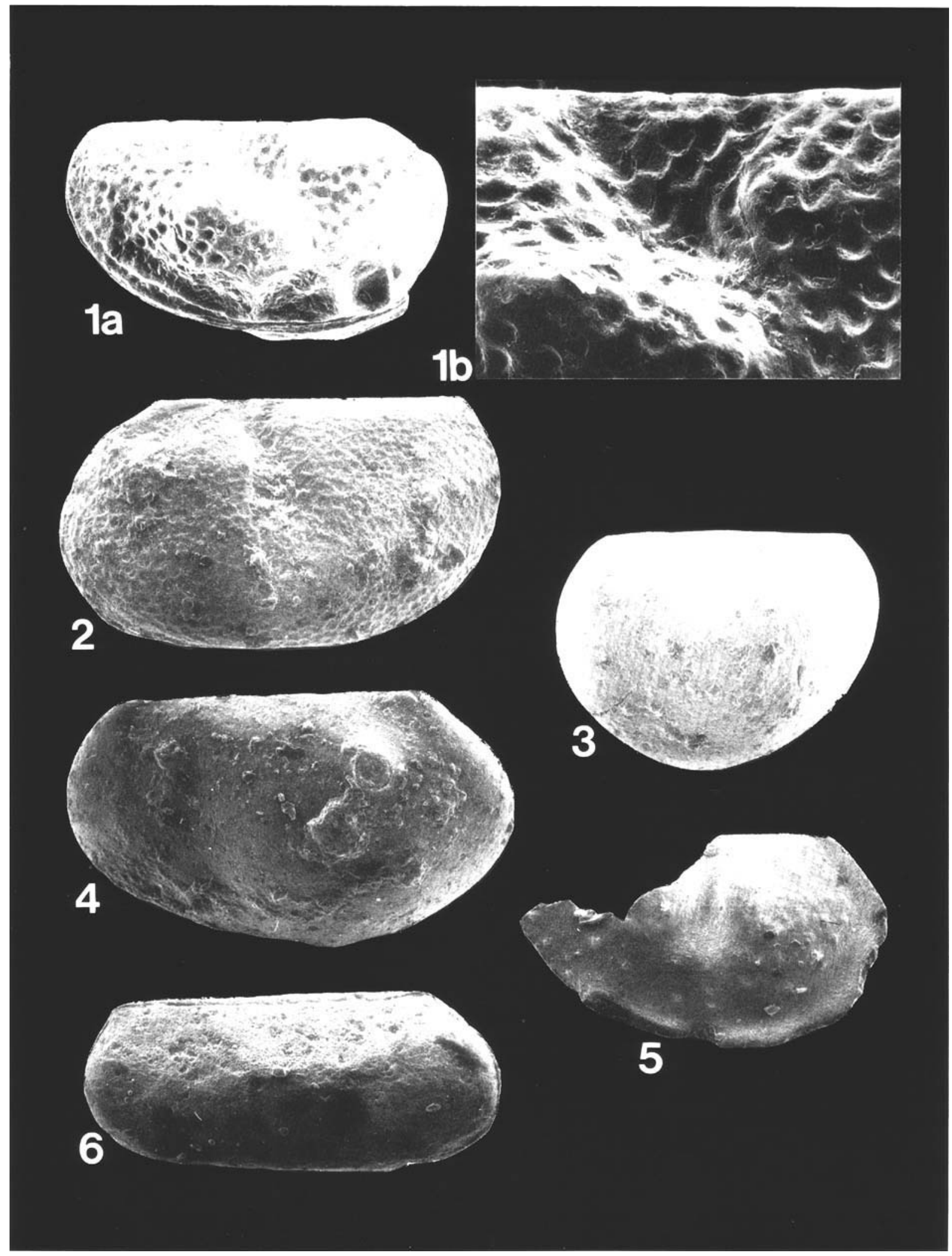


broadly rounded extremity above mid-height, and a posterior, bluntly pointed extremity below mid-height. Anteroand posteroventral margins convex. Surface smooth.

Material. 2 carapaces.

Occurrence. Carboniferous of Great Britain and U.S.A. (Sohn, 1960)

Genus Rectobairdia (Sohn, 1960)

Remarks. Some authors consider Rectobairdia as a genus (e.g. Sohn, 1960 and Bless et al., 1981) or a subgenus of Bairdia (e.g. Crasquin, 1984)

Rectobairdia bavarica sp. nov. (Fig. 12)

1865 Bairdia hisingeri - Jones \& Kirkby, p. 408, Pl. 20, figs. $12 \mathrm{a}-\mathrm{c}$.

?1960 Rectobairdia sp. E - Sohn, p. 56.

Derivation of name. After Bavaria. Specimens of this species that were obtained from the Carboniferous Limestone at Regitzlosan, near Hof in Bavaria, Germany, were described by Jones \& Kirkby (1865), and, together with several different species, assigned to Bairdia hisingeri (Münster, 1830).

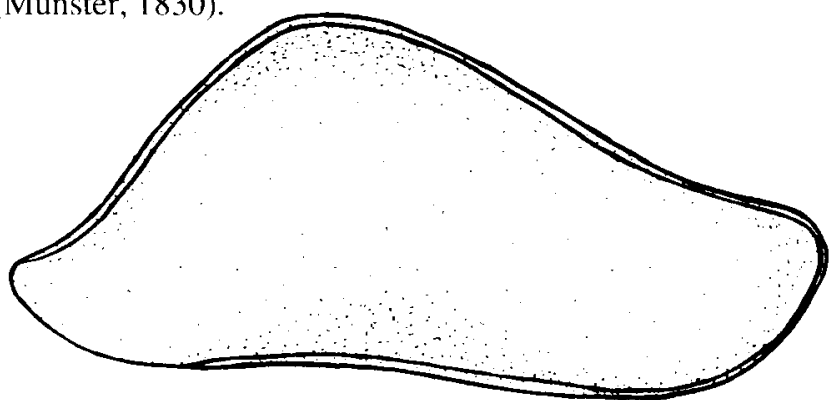

Fig. 12 Rectobairdia bavarica n. sp. (outside right valve; $25 \mathrm{x}$ ).

Diagnosis. Carapace subelongate, DM highly arched, VM slightly concave medianally, ends acuminate. Posterodorsal slope steep and flatly concave, anterodorsal margin longer and slightly concave. Posterior end bluntly pointed below mid-height, anterior end broader. Antero- and posteroventral margins convex. Maximum height posterior to midlength, maximum width central. Surface smooth.

Holotype. RGM 350.611

Paratype. RGM 350.612

Material. 1 carapace and 1 valve.
Type locality. See Fig. 2. It corresponds to locality 55 of Moore (1958) and section 5 of Masurel (1987: fig. 1) in Bishopdale, northern England.

Remarks. The various species that have been assigned to Bairdia hisingeri (Münster, 1830), including this one, were later separated by Sohn (1960).

Occurrence. Carboniferous of Germany and Great Britain.

Genus Bairdiolites Croneis \& Gale, 1939

Bairdiolites elevatus Robinson, 1959

(Pl. 9, figs. 1-4.)

1959 Bairdiolites elevatus - Robinson, p. 441, Fig. 1: 1a.c.

1978 Bairdiolites elevatus - Robinson, p. 154, Pl. 13, figs. 4ab.

Material. 9 carapaces.

Occurrence. Upper Brigantian of Great Britain.

Family Bairdiocypridae Shaver, 1961

Genus Bairdiocypris Kegel, 1932

Bairdiocypris fomikhaensis Bushmina, 1968

(Pl. 8, figs. 3-4.)

1968 Bairdiocypris fomikhaensis - Bushmina, p. 95, PI. 6 , fig. 5, Pl. 17, figs. 1-3, Pl. 18, fig. 1.

1970 Bairdiocypris fomikhaensis - Bushmina, p. 29, PI. 8, figs. 1-3.

1975 Bairdiocypris fomikhaensis - Bushmina, p. 53, PI. 8, fig. 3.

? 1981 Bairdiocypris cf. rudolphi - Bless et al., p. 150-151, Pl. 4, figs. 58-61.

1984 Bairdiocypris fomikhaensis - Crasquin, p. 62, Pl. 8, fig. 10.

1987 Bairdiocypris fomikhaensis - Crasquin, p. 56, Pl. 10, figs. $8-11$.

Diagnosis. Carapace subtriangular in lateral view, DM of right valve gently angular, LV overlapping. Maximum height just anterior to mid-length. VM gently concave, ends rounded, anterior slightly narrower and pointed in dorsal view. Surface smooth.

Material. 9 carapaces and 11 single valves or fragments.

Remarks. B. fomikhaensis has not been recorded from British strata before. The specimens that are illustrated in this paper closely resemble those described from Lower Tournaisian to Upper Visean strata of France (Crasquin, 1984, 1987), and from the Tournaisian of Russia (Bushmina,

\section{Explanation of Plate 8}

Fig. 1 Cavellina cf. benniei (Jones, Kirkby \& Brady, 1884), RGM 350. 638, 25 cm, LV, L 0.74 mm, H 0.34 mm (x 100)

Fig. 2 Cryptophyllus sp., RGM 350.553, $25 \mathrm{~cm}, \mathrm{~L} 0.57 \mathrm{~mm}, \mathrm{H} 0.42 \mathrm{~mm}$ (x 120).

Figs. 3-4 Bairdiocypris fomikhaensis Bushmina, 1968.

Fig. 3 RGM 350. 620, $870 \mathrm{~cm}$, RV, L $0.80 \mathrm{~mm}, \mathrm{H} 0.46 \mathrm{~mm}$ (x 100).

Fig. 4 RGM 350. 621, $920 \mathrm{~cm}$ RV L $0.45 \mathrm{~mm}, \mathrm{H} 0.32 \mathrm{~mm}$ (x 120).

Fig. 5 Bairdiacypris sp. aff. robusta Kummerow, 1939, RGM 350.606, $550 \mathrm{~cm}, \mathrm{RV}, \mathrm{L} 0.52 \mathrm{~mm}, \mathrm{H} 0.26 \mathrm{~mm}(\mathrm{x})$

Figs. 6-7 Bairdiacypris subelongata (Jones \& Kirkby, 1879).

Fig. 6 RGM 350.598, $845 \mathrm{~cm} \mathrm{LV,} \mathrm{L} 1.23 \mathrm{~mm}, \mathrm{H} 0.51 \mathrm{~mm}$ (x 5.5).

Fig. 7 RGM 350, 599, $870 \mathrm{~cm}, \mathrm{RV}, \mathrm{L} 1.25 \mathrm{~mm}, \mathrm{H} 0.49 \mathrm{~mm}$ (x 55) 


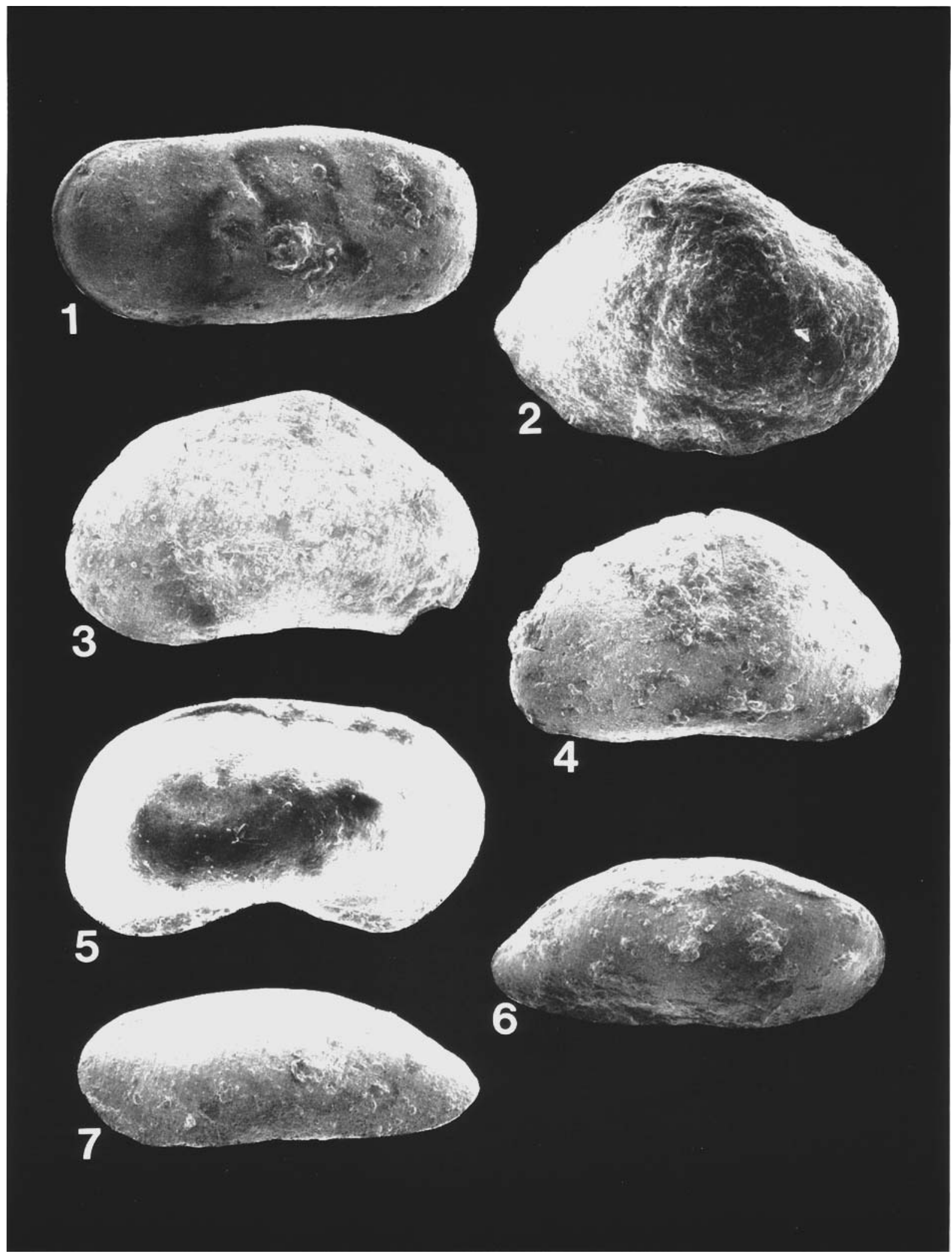


1968, 1970, 1975). Bless et al. (1981) suggested a close relationship with Bairdiocypris cf. rudolphi (Kummerow, 1939) from the uppermost Famennian to Upper Visean of Belgium (Becker \& Bless, 1974) and late Dinantian Carbonates of N. Belgium (Bless et al., 1981), also with B. bilobatus (Münster, 1830) sensu Kummerow, 1939 from the Lower Visean of Belgium and Germany (Becker \& Bless, 1974).

Suborder Cytherocopina Gründel, 1967

Superfamily Cytheracea Baird, 1850

Family Bythocytheridae Sars, 1926

Genus Monoceratina Roth, 1928

Monoceratina antiqua (Jones \& Kirkby, 1886)

1886 Bythocythere antiqua - Jones \& Kirkby, p. 263, Pl. 9, figs. 5a,b.

1956 Monoceratina antiqua - Posner in Zanina, p. 194-195, Pl. 1, fig. 3.

1978 Monoceratina antiqua - Robinson, p. 140, Pl. 6, figs. $4 a, b$.

1983 Monoceratina antiqua - Dewey, p. 113, fig. 6J.

? 1977 Monoceratina? sp. - Sohn, p. 150, Pl. 2, fig. 17.

1987 Monoceratina antiqua - Dewey \& Fåhraeus, p. 105, Pl. 4, figs. 17-20.

Diagnosis. Carapace subrhomboidal in lateral view, tumid. DM long and straight, VM convex, anterior end broadly convex. Posterior end flatly convex, projecting above. Cardinal angles obtuse, marginal rim distinct along anterior and posterior margins, narrow along VM. Wing-like expansions or alae, most developed posteriorly, with a dorsoventral, backwards pointing thorn-like spine on each valve. Median sulcus faint, extending to centre of valve. Surface pitted.

Material. I carapace.

Occurrence. Summarised by Dewey (1987): Newfoundland, Great Britain, U.S.S.R., U.S.A. The range of this species, known from Chadian to Asbian strata of Great Britain (Robinson, 1978), is now extended to the Upper Brigantian stage. Dewey (1987) also suggested a possible extension of the species range to the Upper Chesterian of the Midcontinent of U.S.A.

Order indet.

Suborder Paraparchiticopina Gramm, 1975

Superfamily Paraparchitacea Scott, 1959
Family Paraparchitidae Scott, 1959

Genus Shishaella Sohn, 1971

Shishaella cf. williamsae Sohn, 1971

(PI. 7, fig. 3.)

Diagnosis. Carapace subcircular in lateral view. DM gently convex, VM broadly convex, ends almost equally rounded. Maximum height just anterior to mid-length. Dorsoposterior spine very close to the dorsal margin of the right valve. Surface smooth.

Material. 3 valves.

Occurrence. $S$ williamsae has been recorded from the Upper Mississippian (Lower Meramecian) of Alaska (Sohn, 1971).

Genus Shivaella Sohn, 1971

Shivaella armstrongiana (Jones \& Kirkby, 1886)

(P1. 7, fig. 4.)

1886 Leperditia armstrongiana - Jones \& Kirkby,p. 253, PI. 7, fig. 1

1932 Paraparchites armstrongianus - Latham, p. 356, fig. 4. 1971 Shivaella armstrongiana - Sohn, p. 8-9.

Diagnosis. Carapace subovate in lateral view, DM straight, VM convex, ends broadly rounded. Posterodorsal spine, surface smooth.

Material. I left valve.

Remarks. The lateral outline of the only specimen is slightly obscured by compaction in the sediment, a circular stump indicates the position of the posterodorsal spine.

Occurrence. Courceyan to Arnsbergian of Great Britain. It may be conspecific with Shivaella cf. armstrongiana from the late Dinantian of Belgium (Bless et al., 1981, p. 146, PI. 1, figs. 5-8), S. quasiporrecta (Bushmina, 1968) from the Tournaisian of U.S.S.R., and S. bucera (Kummerow, 1953) from the Dinantian of Poland.

Order indet

Superfamily Quasillitacea Coryell \& Malkin, 1936 Family Quasillitidae Coryell \& Malkin, 1936 Genus? Eriella Stewart \& Hendrix , 1945 ?Eriella minima sp. nov.

(Pl. 3, figs. 6a,b)

Derivation of name. Latin, referring to the relatively small size (compared to that of other species of Eriella).

\section{Explanation of Plate 9}

Figs. 1-4 Bairdiolites elevatus Robinson 1959.

Fig. 1 RGM 350. 615, $25 \mathrm{~cm}$, RV, L $0.90 \mathrm{~mm}, \mathrm{H} 0.45 \mathrm{~mm}$ (x 70)

Fig. 2 RGM 350. 616, $25 \mathrm{~cm}, \mathrm{RV}, \mathrm{L} 1.05 \mathrm{~mm}, \mathrm{H} 0.53 \mathrm{~mm}(\mathrm{x} 70)$

Fig. 3 RGM 350.617, $25 \mathrm{~cm}$, dorsal view, L $0.95 \mathrm{~mm}, \mathrm{H} 0.50 \mathrm{~mm}$ (x 70)

Fig. 4 RGM $350.618,25 \mathrm{~cm}$, RV, L $0.95 \mathrm{~mm}$, H $0.51 \mathrm{~mm}$ (x 70)

Fig. 5 Bairdia beedei Ulrich \& Bassler, 1906, RGM $350.608,870 \mathrm{~cm}, \mathrm{~L} 1.01 \mathrm{~mm}, \mathrm{H} 0.52 \mathrm{~mm}, \mathrm{LV}$ (x 60).

Fig. 6 Bairdiolites elevatus Robinson 1959 RGM 350. 619, 25 cm, RV, L 0.82 mm, H 0.39 mm (x 80).

Figs. 7-8 Bairdia Harltoni Cooper, 1941.

Fig. 7 RGM 350.611, $895 \mathrm{~cm}, \mathrm{LV}, \mathrm{L} 1.41 \mathrm{~mm}, \mathrm{H} 0.76 \mathrm{~mm}$ (x 55)

Fig. 8 RGM $350.612,920 \mathrm{~cm}, \mathrm{RV}, \mathrm{L} 1.25 \mathrm{~mm}, \mathrm{H} 0.51 \mathrm{~mm}(\mathrm{x} 60)$ 

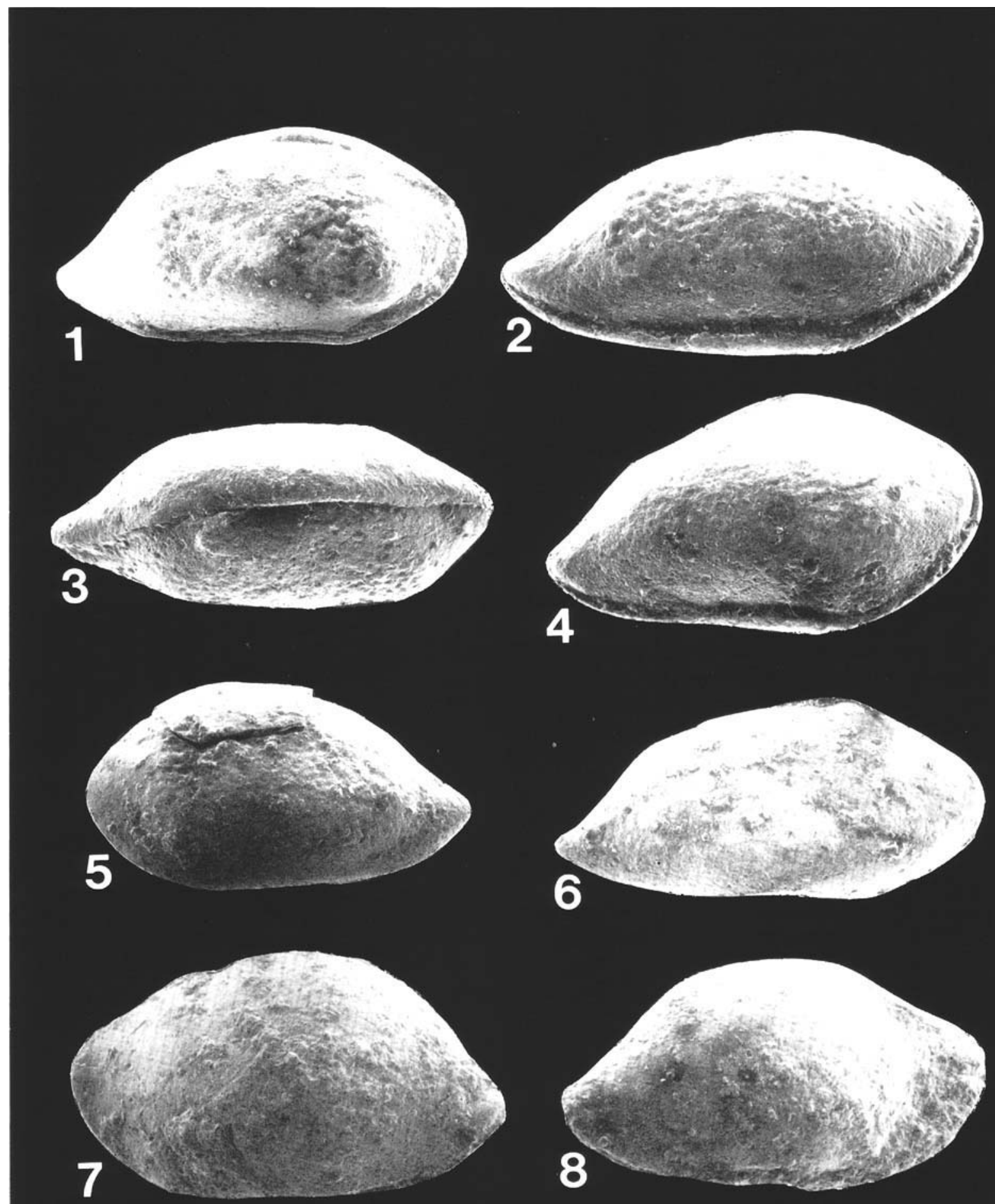
Diagnosis. Carapace oblong, DM straight, hinge line straight and channelled. DM and VM subparallel, ends rounded. LV larger, overlapping RV along the entire margin. Surface regularly reticulated with a central smooth muscle spot.

Holotype. RGM 350. 635

Paratype. RGM 350. 636

Material. 2 carapaces.

Remarks. The species shows similarities in surface ornament to E. ? cribraria Green, 1963 from the Lower Carboniferous Banff Formation, Alberta (Green, 1963, Pl. 14, figs. 9-20). It differs from the type species of Eriella (E. robusta Stewart \& Hendrix , 1945) in the absence of a distinct anteromarginal flange. The generic assignment on this criterion is therefore doubtful (Bless \& Massa, 1982). However, the occurrence of another species with strong affinities to Eriella and lacking distinct marginal flanges, $E$. ? courceyana (Robinson, 1978, Pl. 10, figs. 6a,b), implies that the development of the antero-marginal flange may be of minor diagnostic importance, as already assumed by Robinson (1978).

\section{Order Platycopida Sars, 1866 \\ Suborder Platycopina Sars, 1866 \\ Superfamily Cytherellacea Sars, 1866 \\ Family Cavellinidae Egorov, 1950 \\ Genus Cavellina Coryell, 1928 \\ Cavellina cf. benniei (Jones, Kirkby \& Brady, 1884)}

(Pl. 8, fig. 1)

Diagnosis. Carapace elongate-quadrate in lateral view. DM and VM almost straight and subparallel, dorsum incurved. Valves compressed anteriorly and swollen posteriorly. Anterior end rounded, posterior end almost straight. Central muscle spot just above mid-length. RV larger, overlap most prominent along the anterior margin. Surface smooth.

Material. I carapace.

Remarks. $C$. bennie $i$ shows a considerable variation in size and shape (Jones, Kirkby \& Brady, 1884), a study of which might lead to subdivision.

Occurrence. Robinson (1978, p. 132, Pl. 2, fig. 1) described $C$. benniei, ranging from the uppermost Brigantian to Arnsbergian of Great Britain.

$$
\begin{gathered}
\text { ?Class Ostracoda Latreille, } 1806 \\
\text { Genus Cryptophyllus Levinson, } 1951 \\
\text { Cryptophyllus sp. }
\end{gathered}
$$$$
\text { (PI. 8, fig. 2.) }
$$

Diagnosis. Carapace umbonate, greatest width at about midheight, greatest length ventral. Hinge line short, depressed below the dorsal order. Ventral, anterior and posterior borders rounded, ventral broader. Antero- and posterodorsal borders straight or slightly concave.

Material. 9 carapaces, generally poorly preserved.

Remarks. A variable number of delicate concentric ridges ( 7 or more) is detected on the surface of some of the specimens examined.

\section{ACKNOWLEDGEMENTS}

The author would like to thank J. E. Whittaker and W. Ball, the Keeper of Palaeontology (British Museum of Natural History, Great Britain), Chris Dewey (Mississippi State University, U.S.A.) and M.N. Gramm (Institute of Biology and Pedology, U.S.S.R.); R. Swennen (Kath. University of Leuven, Belgium) is thanked for providing petrographical analyses and Martin Bless (Museum of Natural History, Maastricht, The Netherlands) for valuable suggestions.

This research was supported by grants from two Dutch foundations, the 'Stichting Dr. H. Muller's Vaderlandsch Fonds' and the 'Haak Bastiaanse Kuneman Stichting', both of which are gratefully acknowledged. I particularly wish to thank Bert Boekschoten (Instituut voor Aardwetenschappen, Amsterdam, The Netherlands) and Martin Bless for critically reading the manuscript.

\section{Manuscript received September 1988 \\ Revised manuscript accepted June 1989}

\section{REFERENCES}

Amerom, H. W. J. van, Bless, M. J. M. \& Winkler-Prins, C. F., 1970. Some palaeontological and stratigraphic aspects of the upper Carboniferous Sama Formation (Asturias, Spain). Meded. Rijks geol. Dienst, N.S, 21, 9-79.

Astin, I. R. \& Scotchmans, I. C., 1988. The diagenetic history of some septaria concretions from the Kimmeridge Clay. Sedimentology, 35, 349-368.

Becker, G., 1978. Flachwasser-Ostracoden aus dem hohen Westfal Asturiens (Kantabrisches Gebirge, N-Spanien). 1. Palaeocopida. Senckenbergiana Lethaea, 59, 37-69.

Becker, G. \& Bless, M. J. M., 1974. Ostracode stratigraphy of the Ardenno-Rhenish Devonian and Dinantian. Intern. Symp. Belgian Micropaleont. Limits, Namur, 1, 1-52.

Becker, G. \& Bless, M. J. M., Streel, M. \& Thorez, J., 1974. Palynology and ostracode distribution in the upper Devonian and basal Dinantian of Belgium and their dependence of sedimentary facies. Meded. Rijks geol Dienst, Leiden, Nieuwe Serie, 25, no. 2, 99 pp.

Bless, M.J.M., 1983. Late Devonian and Carboniferous ostracode assemblages and their relationship to the depositional environment. Geologie, Berlin, 92, 31-53.

Bless, M.J.M. \& Jordan, H., 1972. Ostracodes of the family Hollinellidae. Meded. Rijks geol. Dienst, Ser. C49, 1 158.

Bless, M.J.M., Boonen, P., Dusar, M., Soille, P., 1981. Microfossils and depositional environment of late Dinantian carbonates at Heibaart (Northern Belgium). Ann. Soc. Géol. Belg., 104, 135-165.

Bless, M.J.M. \& Massa, D., 1982. Carboniferous ostracodes in the Rhamad $\AA$ s Basin of western Libya: Palaeoecological implications and comparison with North America, Europe and the U.S.S.R. Rev. Instit. francais Pétrole, 37, no. 1, 19-61.

Bradfield, H. H., 1935. Pennsylvanian ostracodes of the Ardmore Basin, Oklahoma. Bull. Am. Paleontology, 22, no. 73, $172 \mathrm{pp}$.

Brondos, M. D. \& Kaesler, R. L., 1976. Diversity of 
assemblages of late Paleozoic Ostracoda. In Scott, R. \& West, R. (Eds.), Structure and classification of paleocommunities: Stroudsburg, Pennsylvania, Dowden, Hutchinson and Ross, 231-234.

Bushmina, L.S., 1968. Early Carboniferous ostracodes from the Kuznetzk Basin. Acad. Nauk S.S.S.R., 1-128 (in Russian).

Bushmina, L.S., 1970. Carboniferous ostracodes of the lower course of the river Lena. Trudy Instit. Geol. Geophys. ANSSSR, Sib. otb., 125, 80 pp. (in Russian).

Bushmina, L. S., 1975. Early Carboniferous Ostracodes of the Kolimian Massif. Trans. Instit. Geol. Geophys. Acad. Sci. S.S.S.R., Sib. Div., 219, 3-103 (in Russian).

Conil, R., Austin, R., Bless, M., Dil, N., Groessens, E., Lees, A., Longerstaey, P., Lys, M., Paproth, E., Pirlet, H., Ramsbottom, W.H.C. and Sevasopulo, G., 1976. International correlation of Dinantian strata. Meded. Rijks Geol. Dienst, N.S., 27 (3), Appendix .

Cooper, C. L., 1941. Chester ostracodes of Illinois. Illinois Geol. Surv. Rep. Invest., 77, 1-101.

Cooper, C. L., 1946 Pennsylvanian ostracodes of Illinois. Bull. Illinois State Geol. Surv., 70,9-177.

Cooper. C. L., 1947. Upper Kincaid (Mississippian) microfauna from Johnson County. Illinois Geol. Surv. Rep. Invest., 122, $55 \mathrm{pp}$.

Crasquin, S., 1984. L'Ecozone à Bairdiacea et Paraparchitacea (Ostracoda) au Dinantien. Geobios, 17. fasc. 3, 341-348.

Crasquin, S., 1986. Les Ostracodes Dinantiens du Synclinal de Laval et du Synclinorium de Namur (SystématiquéBiostratigraphie-Paléoécologie). Thesis Univ. Lille Flandres-Artois (unpubl.), part 1, 169 pp., part 2, 71 pp.

Croneis, C., \& Gale, A. S., 1938. New ostracodes from the Golconda Formation. Denison Univ. Sci. Lah. Jowr., 33 . art. 5, 251-295.

Devery, H. B., 1987. Analysis of the microfarma, facies variation, and stratigraphy of selected outcrops of the Bangor Limestone (Chesterian; Mississippiam) in Colbert. Franklin, and Lawrence Countics. Northu'est Alabama. MSc-Thesis, Mississippi State Univ. (unpubl.), 206 pp.

Dewey, C. P., 1983. Ostracode palaeoecology of the lower Carboniferous of western Newfoundland. $8 t h$. Inter. Symp. on Ostracoda, Houston, 104-115.

Dewey, C.P., 1985. The Palaeobiogeographic significance of Lower Carboniferous Crustaceans (Ostracodes and Peracards) from western Newfoundland and central Nova Scotia, Canada. Palaeogegr.. Palaeoclim., Palaeooec., 49, 175-188.

Dewey, C. P., 1987. Palaeoecology of a hypersaline Carboniferous ostracod fauna. J. micropalaeontol., 612), 29-33.

Dewey, C.P., \& Fîhraeus, L. E., 1987. Taxonomy of Ostracoda (Crustacea)from Mississippian Strata of Maritime Canada. Geol. et Palacont., 21, 93-135.

George, T. N., Johnson, G. A., Mitchell, J. G., Prentice, J. G., Ramsbottom, W. H. C., Sevastopulo, G. D., Wilson, R.
R., 1976. A correlation of Dinantian rocks in the British Isles. Geol. Soc. of Lond. Spec. Rep. 7, 1-87.

Gramm, M. N., 1982. The systematic position of the ostracode genus Healdianella Posner, 1951. In Bate R. H., Robinson, E. \& Sheppard,L. M.(Eds.). FossilandRecent Ostracodes, 193-218, Chichester (Ellis Horwood).

Green, R., 1963. Lower Mississippian ostracodes from the Banff Formation, Alberta. Res. Council Alberta Bull. 11, 237 pp.

Haack, R. C. \& Kaesler, R. L., 1980. Upper Carboniferous ostracode assemblages from a mixed carbonateterrigenous-mud environment. Lethaia, 13, 147-156.

Harlton, B. H., 1927. Some Pennsylvanian Ostracoda of the Glenn and Hox bar formations of southern Oklahoma and the upper part of the Cisco formation of northern Texas: Jour. Paleontology, 2, 203-212.

Harlton, B. H., 1929. Some Upper Mississippian (Fayetteville) and Lower Pennsylvanian (WapanuckaMorrow) Ostracoda of Oklahoma and Arkansas. Am. Jour. Sci., Sth ser., 18, 254-270.

Higgins, A. C., 1981. The distribution of conodonts in relation to the palaeogeography of late Visean-Namurian time. In Neale, J. W. \& Brasier, M. D. (Eds.). Microfossils from recent and fossil shelf seas, 37-51, Chichester (Ellis Horwood).

Jones, T. R., 1859. In Kirkby, J. W., On Permian Entomostraca from the shell-limestone of Durham, with notes on the species by T. R. Jones. Tyneside Naturalists' Field Cluh Trans., 4, 122-171.

Jones, T. R., 1870. On ancient waterfleas of the Ostracodous and Phyllopodous tribes (Bivalved Entomostraca). Monthly Micro. Jour., 4, 184-198.

Jones, T. R., \& Kirkby, J. W., 1865. Notes on the Paleozoic bivalved Entomostraca. No. V. Münster's species from the Carboniferous Limestone. Annals Mag. Nat. History, ser. 3, v. 15, 404-410.

Jones, T. R. \& Kirkby, J. W., 1879. Description of the species of the ostracodous genus Bairdia McCoy, from the Carboniferous strata of Great Britain. Geol. Soc. London Quart. Jour., 35, 565-581.

Jones, T. R. \& Kirkby.J. W., 1884. On some Carboniferous Entomostraca from Nova Scotia. Geol. Mag. N.S., Dec. 3. $1: 356-362$.

Jones, T. R. \& Kirkby, J. W., 1885. Notes on the Paleozoic Bivalved Entomostraca. No. XIX. On some Carboniferous species of the ostracodous genus Kirkbya, Jones. Annals Mag. Nat. History, ser. 5, v. 15, 174-191.

Jones. T. R.\& Kirkby, J. W., 1886. Notes on the Paleozoic bivalved Entomostraca. No. XXII. On some undescribed species of British Carboniferous Ostracoda. Annals Mag. Nat. History, ser. 5, v. 18, 249-269.

Jones, T. R. \& Kirkby, J. W., 1892. Notes on the Paleozoic bivalved Entomostraca. No. XXX. On Carboniferous Ostracoda from Mongolia. Annals Mag. Nat. Hist., ser. 6, v. 9, 302-307.

Jones, T. R., Kirkby, J. W. \& Brady, G. S., 1884. A 
monograph of the British fossil bivalved Entomostraca from the Carboniferous formations. London, Palaeontogr. Soc., 57-92.

Kaesler, R. L., 1983. Ostracoda from Pennsylvanian subsurface shales, environmental indicators. In Maddock, R. F. (Ed.). Applications of Ostracoda. Proc. 8th Int. Symp. on Ostracoda, Houston, 116-132.

Knight, J. B., 1928. Some Pennsylvanian ostracodes from the Henrietta formation of Eastern Missouri. Jour. Paleontology, 2, 229-267.

Kornicker, L. S., Ecology and taxonomy of recent Bairdiinae (Ostracoda) Micropaleontology, 7, 55-70.

Kummerow, E., 1939. Die Ostracoden und Phyllopoden des Deutschen Unterkarbon. Abh. preuss. geol. L. Anst., N.F. 194, $1-107$.

Kummerow, E., 1953. Uber oberkarbonische und devonische ostracoden in Deutschland und in der Volksrepublik Polen. Staat. Geol. Komm. Deutsch. Demokrat. Republik, Geologie, Jahrg. 2, Beih. 7, Berlin, 75 pp.

Latham, M.H., 1932. Scottish Carboniferous Ostracoda. Trans. Roy. Soc. Edinburgh, 57, 351-395.

Levinton, J. S., 1970. The palaeoecological significance of opportunistic species. Lethaia 3, 69-78.

Mamet, B.L., 1970. Carbonate micro facies of the Windsor Group (Carboniferous), Nova Scotia and New Brunswick. Geol. Surv. Can. Pap. 70-71, 121 pp.

Masurel, H., 1987. Macrofossils and their palaeoecology in deltaic sequences of the Lower Carboniferous Yoredale Series, Yorkshire, England. Geologie en Mijnbouw 66, 221-237.

McElhinny, M. W., 1973. Palaeomagnetism and plate tectonics. Cambridge Univ. Press, $358 \mathrm{pp}$.

Melnyk, D. M., 1985. Biofacies and ostracode biostratigraphy of the Permo-Carboniferous of central and north-central Texas: The application of numerical techniques to the recognition of biozones and biofacies in a depositionally complex sequence. Ph.D. - Thesis, Univ. of Houston, $439 \mathrm{pp}$.

Moore, D. G., 1958. The Yoredale Series of Upper Wensleydale and adjacent parts of Great Britain. Yorks. Geol. Soc. Proc. 31, 91-148.

Moore, R. C. (Ed.), 1961. Treatise on Invertebrate Palaeontology Part Q, Arthropoda 3, Ostracoda 442 pp. New York (Univ. Kansas Press).

$\mathrm{M}$ fnster, G., 1830. Uber einige fossile Arten Cypris und Cythere. Jb. Miner Geogn. Petrefaktenk. 1, 60-67.

Neale, J. W., 1984. The Ostracoda and Uniformitarianism. II. The earlier record: Cretaceous to Cambrian. Proc. Yorks. geol. Soc. 44, no. 31, 443-478.
Posner, V. M., 1951. Lower Carboniferous Ostracoda of the western part of the Moscow Kettle Valley. VN/GRI 56, 1 139, Leningrad-Moskva (in Russian).

Robinson, J. E., 1959. The ostracod fauna of the shale facies of the Cawdor Limestones, north end Cawdor Quarry, Derbyshire. Geol. Soc. London Quart. Jour. 114, 435448.

Robinson, E., 1978. The Carboniferous. In Bate, R. \& Robinson, E. (Eds.). A stratigraphical index of British Ostracoda, p. 121-166, Liverpool (See House Press).

Sohn, I. G., 1954. Ostracoda from the Permian of the Glass Mountains, Texas. United States Geol. Surv. Prof. Pap. 264-A, 1-24.

Sohn, I. G., 1960. Paleozoic species of Bairdia and related genera. United States Geol. Surv. Prof. Pap. 330-A, 1 105.

Sohn, 1. G., 1961 Aechminella, Amphissites, Kirkbyella and related genera. United States Geol. Surv. Prof. Pap. 330B, $107-160$.

Sohn, I. G., 1971. New Late Mississippian Ostracode genera and species from northern Alaska; a revision of the Paraparchitacea. United States Geol. Surv. Prof. Pap. 711-A, 1-24.

Sohn, I.G., 1977. Late Mississippian and early Pennsylvanian Ostracoda from northern Arkansas - a preliminary survey. Oklahoma geol. Surv. Guide Book 18, 149-159.

Ulrich, E. O. \& Bassler, R. S., 1906. New American Paleozoic Ostracoda. Notes and descriptions of Upper Carboniferous genera and species. Proc. United States Nat. Mus., Washington, v. 30, 149-164.

Ulrich, E. O. \& Bassler, R. S., 1908. New American Palaeozoic Ostracoda preliminary revision of the Beyrichiidae with descriptions of new genera.Proc. Unitcd States Nat. Mus., Washington, v. 35, 277-341.

Vandenberge, N. \& Laga, P., 19986. The septaria of the Boom Clay (Rupelian) in its type area in Belgium. Aardk. Meded., 3, 229-238.

Vine, G. R., 1884. Notes on the Carboniferous Entomostraca and Foraminifera of the north Yorkshire shales. Yorks. Geol. Polytechn. Soc. Proc., new ser., v. 8, 226-239.

Zanina, I., 1956. Ostracodes from the Viséan Stage of the Pod-Moskow Basin. Trudy, VNIGRI, 98, 185-310, Leningrad (in Russian).

Ziegler, A. M., Scotese, C. R., McKerrow, W. S., Johnson, M. E. \& Bambach, R. K., 1979. Palaeozoic palaeogeography. Annu. rev. Earth Planet. Sci. 7, 473502. 